CENTRE FOR VOCATIONAL EDUCATION RESEARCH

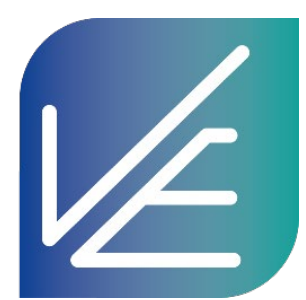

Socio-economic inequality and academic match among post-compulsory education participants

Konstantina Maragkou

Research Discussion Paper 023

September 2019

CENTRE fOR ECONOMAC
PER R OR M ANCE 
The Centre for Vocational Education Research (CVER) is an independent research centre funded by the UK Department for Education (DfE). CVER brings together four partners: the LSE Centre for Economic Performance; University of Sheffield; National Institute of Economic and Social Research and London Economics.

Any views expressed are those of the authors, and do not represent the views of DfE. For more details on the Centre, go to cver.Ise.ac.uk

Published by:

Centre for Vocational Educational Research

London School of Economics \& Political Science

Houghton Street

London WC2A 2AE

All rights reserved. No part of this publication may be reproduced, stored in a retrieval system or transmitted in any form or by any means without the prior permission in writing of the publisher nor be issued to the public or circulated in any form other than that in which it is published.

Requests for permission to reproduce any article or part of the Working Paper should be sent to the editor at the above address.

(C) K. Maragkou, September 2019. 


\title{
Socio-economic inequality and academic match among post-compulsory education participants*
}

\author{
Konstantina Maragkou ${ }^{\dagger}$ \\ University of Sheffield and CVER
}

September 14, 2019

\begin{abstract}
The study investigates the impact of socio-economic background on the academic match of students in post-compulsory upper-secondary education making use of detailed individuallevel linked administrative data from schools, colleges and tax authorities in England. Academic match occurs when student quality matches the quality of the qualification that they take and is measured using a continuous variable which defines undermatched, matched and overmatched students based on the distance between each student's prior attainment in age 16 high-stake examinations and the median prior attainment of the other students who achieved their chosen academic or vocational qualification. Students from socially disadvantaged backgrounds are found to be more likely to be exposed to academic undermatch compared to their more advantaged peers and this effect is identified to be greater among the highest achieving students. Also, the study demonstrates that undermatched students are more likely to be found in schools with lower proportions of high achieving students and higher proportions of disadvantaged students. Among the highest achieving students, $80 \%$ of the identified socio-economic gap in academic match can be explained by such differences in the schools that those students from differing backgrounds attend. In addition, the study identifies indications that significant masses of undermatched students are more likely to be found in rural districts with higher rates of youth unemployment and higher proportions of poorly educated residents. Finally, the study establishes a positive relationship between academic assortative matching and labour market income returns. Non-university participating girls who were one standard deviation less undermatched earned $17 \%$ more at age 25 while non-university participating boys earned $5 \%$ more.
\end{abstract}

Keywords: academic match, post-compulsory education, inequality, social mobility

JEL Classification: I21, I24, I26, J31

${ }^{*}$ The project is funded by the Centre for Vocational Education Research at the London School of Economics (CVER: cver@lse.ac.uk). CVER is an independent research centre funded by the UK Department for Education (DfE). Any views expressed are solely mine and do not represent the views of the DfE. I am grateful to all participants at the Economics PhD Conference (Sheffield, May 2019), the PhD Workshop on Labour and Family Economics (Egham, May 2019), the Edge Foundation seminar (London, June 2019) and ESPE Conference (Bath, June 2019) for useful suggestions. I am particularly thankful to Steven McIntosh, Andy Dickerson, Damon Morris, Olivier Marie, Arnaud Chevalier, Lindsey Macmillan, Sandra McNally, Mark Bryan, Matt Dickson and an anonymous reviewer for valuable comments that helped improve earlier versions of this paper. Any remaining errors are exclusively my own.

${ }^{\dagger}$ Department of Economics, University of Sheffield, 9 Mappin St., Sheffield, S1 4DT. Email: k.maragkou@sheffield.ac.uk 


\section{Introduction}

Improving the quality of the educational system has been an important concern for policy makers as it has been proven to be an effective route away from poverty and a key path to economic prosperity and social inclusion (Black et al., 2015; Jenkins et al., 2003). In light of this, various investigations attempted to raise awareness of the factors causing inequality and social immobility in education. However, little is yet known about the extend of academic match, occurring when the quality of the qualification a student achieves matches their ability credentials; and most importantly whether certain groups of students, especially those who come from a disadvantaged background, are more likely to be exposed to academic mismatch. Several studies reveal that students from low-income families or from ethnic minorities tend to not attend a college or to disproportionately attend less selective colleges, drop out before attaining a degree or graduate with a lower grade (Hearn, 1991; Hoxby and Avery, 2012; Chowdry et al., 2013; Crawford, 2014; Crawford et al., 2016). These poor outcomes are often attributed to disadvantaged students being less academically prepared for college than their more advantaged counterparts (Hoxby and Avery, 2012).

In response to these concerns there is an emerging literature which investigates Higher Education (HE) institution quality and ability match of individuals from socially disadvantaged backgrounds. Recent work from Campbell et al. (2019) identified that socially disadvantaged English students systematically undermatched to their university course. While among the existing literature there is a general consensus with regards to disadvantaged students undermatching into less selective institutions, currently there is no evidence with regards to students' match into pre-university qualifications. This is a seminal area to explore given that inequalities in education have been proven to emerge way before young individuals' entrance into HE. Also, poor achievement in secondary schools has been proven to be more important in explaining low HE participation rates among disadvantaged students than barriers arising at the point of entry to HE (Chowdry et al., 2013). The aim of this study is to make a novel contribution to the literature through investigating the relationship between socio-economic background and academic match at the upper-secondary level making use of detailed individual-level linked administrative data records from schools, colleges and tax authorities in England for the total population of a single cohort born between 1989-1990. 
In upper-secondary education academic undermatch would occur when a student's achievements at the final year of compulsory school, at age 16, would permit access to more highly ranked qualifications than the ones they actually choose. On the other hand, academic overmatch would occur when students chose to study for more highly ranked qualifications when their prior achievements are below those typically seen at that level. It could be, of course, argued that when students are choosing their post-compulsory qualifications are behaving optimally. In theory, non-matched students are not necessarily less likely to perform well in their chosen qualification and they might enjoy all other dimensions of a qualification beyond its academic selectivity. For example, we might define a student as being undermatched because of having the skills to study Advanced Level qualifications (A levels) in three facilitating subjects ${ }^{1}$ but did not. The student, though, might have enjoyed studying the non-facilitating subject for example in Arts or Music. Moreover, undermatched students might gain utility from being the 'big fish in a small pond' (Marsh and Hau, 2003) or from the fact that they will have to deal with less competition from their peers and be able to manage coursework better (Campbell et al., 2019; Dillon and Smith, 2017). On the other hand, overmatched students might benefit from having stronger peers which could lead to better attainment.

However, there are several possible reasons why being undermatched or overmatched might not be desirable. First, it is supported that academic assortative matching ${ }^{2}$ maximises the efficiency of human capital production (Sallee et al., 2008). In addition, students of all academic ability levels have a higher probability of completing a course if the selectivity level matches their academic level (Hoxby and Avery, 2012). Also, undermatched students may have lower quality peers and may therefore be negatively influenced. Further, if the individuals would like to pursue HE then upper-secondary qualifications will be critical on the probability of being accepted on each course and in each university. Academic match in upper-secondary education, therefore, has important implications for social mobility and the life chances of students. Nevertheless, the study makes no claims that obeying academic assortative matching is individually optimal for all students.

The study creates a unique continuous matching index which identifies undermatched,

\footnotetext{
${ }^{1}$ Facilitating subjects are the subjects most commonly required or preferred by universities to get students accepted onto degree courses. Many of the top universities require students to have at least one A level in a facilitating subject when they apply.

${ }^{2}$ Academic assortative matching involves the preferential matching of students to qualifications studied by similarly achieving peers. In other words, academic assortative matching would occur when the most high-achieving students study for the most highly-ranked qualifications.
} 
matched and overmatched individuals in post-compulsory upper-secondary education aiming to uncover socio-economic inequalities causing academic mismatch as well as additional possible correlations between students' background and academic match. It explores regional differences between the most undermatched and most overmatched students as well as differences in their school environments by comparing school composition characteristics such as peers' ability and socio-economic background. Finally, the study examines the short-term labour market returns of academic assortative matching using measures of the students' log daily income at age 25 attempting to shed light on the importance of being academically assortatively matched.

The study is unique in that it is the first to examine academic match at the uppersecondary level and also it is the first to consider students' match in vocational qualifications as all the previous studies considered only academic education as a possible option. The analysis of academic match on vocational qualifications is a crucial contribution that this study provides, especially in the context of England, where there is a complex vocational education system that is little understood by students and employers (more detailed information is provided in the next section). Also, this study is only the second to examine academic match in England in general, after Campbell et al. (2019), as most of the previous analyses are focused on the USA.

The findings suggest that disadvantaged students are more likely to be exposed to academic undermatch even compared to other students within the same school. Further, the study identifies that academically undermatched students are more likely to be found in disadvantaged schools including schools with lower proportions of high achieving students and higher proportions of students who are eligible for a Free School Meal (FSM). The study reveals that significant masses of undermatched students are more likely to be found in rural Local Authorities Districts (LADs) ${ }^{3}$ with higher rates of youth unemployment and higher proportions of poorly educated residents. Finally, the study demonstrates that academic assortative matching in upper-secondary education has a positive relationship with labour market income returns, at least at early ages.

The remainder of this paper is organised as follows. The next section provides institutional context and motivates the study. In Section 3 there is a review of the relevant literature

\footnotetext{
${ }^{3}$ A LAD is a term used to describe geographic areas in England including London Boroughs, Metropolitan Districts, Unitary Authorities and Non-Metropolitan Districts. There are a total of 317 LADs in England.
} 
while Section 4 describes the data. Section 5 explains the econometric model that has been used to examine the relationship between socio-economic background and academic match and Section 6 presents the main findings. Finally, Section 7 concludes this study.

\section{Institutional context and motivation}

In England, the school curriculum is organised in five blocks of years called Key Stages (KS). The students leave secondary education (KS4) at age 16 after undertaking the General Certificate of Secondary Education (GCSE). Following the national GCSE exams, students enter upper-secondary education (KS5) ${ }^{4}$ which usually lasts for two or three years and it is received between the ages of 16-19 in the form of upper-secondary academic or vocational qualifications. Until recently post-16 education used to be non-compulsory while since 2014 the compulsory participation age rose to 18 . The cohort analysed in this study turned 16 in 2006, before the policy change, and therefore has not been affected.

Although the vast majority of students remained in post-16 education (around $80 \%$ of the analytical cohort) the options available concerning where to go and what to study were, and still are, very broad. The students have the option to go to a sixth form in their school (if there is a sixth form in their school) or in another school and study for academic qualifications, they can also go to a sixth form college and finally, they can go to a college of Further Education where they can study mostly vocational qualifications. Both academic and vocational qualifications are divided in levels, the highest being Level 8 qualifications which are equivalent to a doctorate and the lowest being Level 1 qualifications which are equivalent to GCSEs in grades D-G. Level 4 qualifications and above are considered HE qualifications and therefore this study considers students' match to qualifications up to Level 3 which is the highest level in upper-secondary education. The national threshold at the end of compulsory school is to have achieved a Level 2 qualification which is equivalent to GCSEs at grades $\mathrm{A}^{*} \mathrm{C}$.

Unlike HE where access criteria vary substantially depending on institution and course quality, the vast majority of students in upper-secondary education can access their first choice of destination although in some cases there are admissions criteria and capacity constraints. Usually, 5 GCSEs at grades $\mathrm{A}^{*} \mathrm{C}$ or equivalent is the required threshold to continue in Level 3 education. There is a proportion of students who at age 16 do

\footnotetext{
${ }^{4}$ Upper-secondary education is the equivalent education received in the final two years of senior high school in the USA.
} 
not meet the pre-requisites of Level 3 qualifications and must study at Level 2 (i.e. at the same level as GCSE) or even Level 1 or below that (at Entry Level). Although it is possible for students to repeat the GCSE examinations instead of pursuing a noncompulsory vocational qualification the study considers only the students who achieved Level 1 or Level 2 vocational qualifications. In addition, it is possible for students to engage in qualifications of different levels and types simultaneously. This study considers students' match at their highest achieved qualification (highest level) while concerning the different types of qualifications, in the analytical cohort there is only a very small proportion of students (less than 1\%) who achieved both a Level 3 academic and a Level 3 vocational qualification. In that case, the students have been categorised as achieving A levels, which are the main academic qualifications offered, since these qualifications are usually the dominant route to university and also it is rare that people with other types of qualifications make it to a selective institution (Hupkau et al., 2017).

The literature in general finds a positive average income return to qualifications at Level 3 either vocational or academic. However, there are several students that leave the education system with lower level qualifications (below Level 3) and with regards to them there is more controversy over the extent to which these qualifications offer much opportunities in terms of future employment and earnings (Hupkau et al., 2017). Also, while for the students undertaking A levels the route is relatively well-known, for the rest of the students studying vocational qualifications, the available options are much more diverse and not as easy to understand where they lead to (Hupkau et al., 2017). Currently, there is no national structure of the vocational education system and there are thousands of available qualifications (over 12,000) which are offered by more than 150 awarding organisations.

Given, therefore, the complexity of the vocational education system in England (Wolf, 2011), the broad list of options that the students have to choose from and the fact that about $50 \%$ of the students staying in post-compulsory education do not undertake A levels and are therefore exposed to this complex vocational system, make this investigation with regards to whether the course they finally end up studying matches their ability credentials a particularly important research area which should be of major interest to policy-makers concerned with social mobility and equality of opportunity. 


\section{Literature Review}

There is a relatively small but emerging literature that examines academic match and its implications, mainly on university performance and institution prestige. In the current literature, academic undermatch occurs when a student's academic credentials permit access to a college or university that is more selective than the alternative institution they choose. Hoxby and Avery (2012) find that the vast majority of high-attaining students who come from a disadvantaged background do not apply to selective colleges or universities despite the fact that selective institutions would often cost them less due to generous financial aid available for disadvantaged students. The authors also note that the disadvantaged students who do not apply to any prestigious institution despite their high academic achievements tend to come from areas too small to support selective public high schools. Also, compared to other high-achieving disadvantaged students who do apply to prestigious institutions, they tend to have lower achieving peers and are unlikely to encounter a teacher or a schoolmate from an older cohort who attended a selective institution.

Dillon and Smith (2017) defined student-college academic mismatch as the difference between a student's percentile position in the cognitive ability distribution and the student's percentile position in the college's quality distribution of those students who attended a college. Using a sample from the USA born in 1987 they identified substantial amounts of both academic undermatch and academic overmatch from students of all backgrounds. The study mentions that students from less wealthy families undermatch more while more informed students, such as students from high schools where many graduates go to college, undermatch less and overmatch more. Further, the study identifies that academic mismatch is driven mostly from student application and enrolment decisions rather than college admission decisions.

Smith et al. (2013) followed two cohorts of American students, the older finishing school in 1992 and the younger in 2004. They determined the highest academic selectivity college to which the students had access given their academic credentials and compared that college to where the students ultimately enrolled by making use of data on students' applications and admission offers. The study identified that over $40 \%$ of the students undermatched and that undermatch is more common among students from rural areas and for students from low socio-economic backgrounds with less educated parents. Finally their findings 
show that undermatch has decreased between the two cohorts partly because of changing student decisions and because of changing college selectivity.

The study of Roderick et al. (2011) showed that low income urban American students who had the qualifications to attend four-year colleges did not effectively take the steps to apply to and enrol in a four-year college. Also, they found that students enrol in colleges with selectivity levels below the ones that they would be qualified to attend based on their achievements. The study showed that high schools have an important role to play in guiding students into the college application process and shaping the students' choices. Students who attended schools with a higher proportion of college-attending students, where teachers report that they expect students to go to college and take responsibility for their students' college application, and where greater proportions of students are active in financial aid application are more likely to plan to attend, apply to, and be accepted into a college as well as to enrol in a college with selectivity levels that match their qualifications.

Belasco and Trivette (2015) using the same data but a different strategy to identify academic match have also shown that there is a negative and significant relationship between socio-economic background and academic match especially for students living in rural areas. However, the study revealed that the influence of other determinants such as school environment, the provision of information and other college-related interventions play a more important role for academic match than a student's socio-economic background.

Black et al. (2015) focused their study on academic undermatch of high-achieving students from an ethnic minority background using data collected by the Texas Workforce Data Quality Initiative. The study defined undermatch as not applying to a top-tier flagship university while graduating from high school in the top $10 \%$ or in the top $25 \%$ of the senior class's students during 2008 and 2009. The study identified that the phenomenon of undermatch exists even if students have perfect information that they will be admitted. Also the authors mention that automatic university admission contributes to minority applications to elite universities but is not sufficient to fully overcome academic undermatch.

All of the literature discussed above is focused in the USA. The closest paper to the present study is that of Campbell et al. (2019) which is the only study to our knowledge that examines academic undermatch for HE students in England. The study creates a new continuous measure of student-course match quality representing the distance of each 
student's university course from their ideally matched course which would be that attended by others in the same position in the ability distribution. The study identified that highattaining disadvantaged students are more likely to be undermatched on their university course than their more advantaged counterparts and that undermatched students are indicated to live in environments which are less conducive to academic success such as areas that have fewer residents who attended university or areas with fewer universities.

\section{Data}

\subsection{Description of the Datasets}

The analysis of this study has been carried out by making use of individual-level linked administrative data on the whole population of state-school students in England for a single cohort totalling approximately half a million students. This cohort was born in 19891990, took compulsory age 16 examinations (GCSE exams) in 2006 and attended uppersecondary post-compulsory education between 2006-2009. Table 1 outlines the educational progression of the cohort.

\section{Table 1: Education progression of the cohort}

\begin{tabular}{lll}
\hline Academic Year & Age & Event \\
\hline $1989-1990$ & 0 & Born \\
$2000-2001$ & $10-11$ & KS2 exams \\
$2003-2004$ & $13-14$ & KS3 exams \\
$2005-2006$ & $15-16$ & KS4 exams (GCSEs) \\
$2007-2008$ & $17-18$ & KS5 exams (upper-secondary education) \\
$2008-2009$ & $18-19$ & KS5 exams for continuing students \\
\hline
\end{tabular}

The school data come from the National Pupil Database (NPD) and include basic demographic characteristics as well as school outcomes at ages 11 and 14 (KS2 and KS3), public examination results at age 16 (KS4: GCSEs) and age 18 (KS5: usually A levels). The data for vocational qualifications come from the Individualised Learner Record (ILR) dataset which is an administrative dataset covering the population of funded learners in Further Education in England. The ILR contains detailed information on the learning undertaken by individuals, including the learning aim, type of qualification, level, subject area, training provider, start and end dates, and attainment markers. The aggregated earnings data come from the Longitudinal Education Outcomes (LEO) dataset which are compiled from tax records by Her Majesties Revenue and Customs (HMRC) by officials at the Department for Education (DfE) in the UK. 
The data have been also linked to the School Census of 2006 in order to access important information about the composition of schools the cohort attended. Finally, the datasets have been linked to the 2001 Census in order to acquire detailed measures of neighbourhood composition and Local Authority District (LAD) characteristics.

\subsection{Analytical Sample}

The analytical sample is composed of students who went to state-schools in England and achieved at least one post-compulsory upper-secondary qualification. From the initial cohort of about 555,000 students there is a moderate censoring since a proportion of the students left education after compulsory examination at age 16 or attempted an uppersecondary qualification but did not achieve it (around $23 \%$ of the cohort) ${ }^{5}$. The final analytical sample is composed of over 390,000 students with non-missing information on socio-economic background, test scores at ages 11 and 14 and exam scores at age 16, demographics at age 16 and secondary school attended. Although the final analytical sample includes only post-compulsory education participants with non-missing background information the total sample has been used to construct variables such as the socio-economic background index, GCSE scores to identify the selectivity of each upper-secondary qualification and to standardise prior achievement (KS2, KS3 and KS4).

Table 2 shows the attrition details of the sample. The analytical sample has a higher average prior attainment than the total sample which is not surprising given that the study is focused only on post-compulsory education participants who achieved an uppersecondary qualification. We would expect that these students would be higher achieving than the total sample which includes the students who dropped out from education or had attempted a post-compulsory qualification but did not achieve it. Apart from that, in terms of other background characteristics, the analytical sample did not significantly differ from the total sample.

Table 2: Attrition Details

\begin{tabular}{lc}
\hline Sub-sample & Observations \\
\hline Total in cohort & 555,601 \\
Total post-compulsory education participants & 428,802 \\
Non-missing background characteristics & 391,651 \\
\hline Analytical sample & $\mathbf{3 9 1 , 6 5 1}$ \\
\hline
\end{tabular}

\footnotetext{
${ }^{5}$ In the future it would be interesting to consider academic match in 'highest attempted' upper-secondary qualification rather than 'highest achieved' qualification and examine the extent to which students who where matched to their qualification had a higher probability of achieving it.
} 


\subsection{Variables}

\section{Dependent Variable}

\section{Step 1: Ranking upper-secondary qualifications in order of selectivity}

The analysis is based on categorising the many different types of upper-secondary qualifications available into five broad categories. These categories include Level 3 academic qualifications, including A levels and AS levels, Level 3 vocational qualifications, Level 2 vocational qualifications and Level 1 vocational qualifications. Making use of information published by the Russell-Group (selective) university guidance ${ }^{6}$ the study distinguishes between students who studied for A levels which include three or more facilitating subjects, two facilitating subjects, one facilitating subject and those who studied for A levels but not in a facilitating subject ${ }^{7}$. The outcome is a categorical variable of 11 different classifications indicating the highest upper-secondary qualification each individual achieved by 2009 (age 19). Then, the selectivity of each qualification is identified based on the median standardised GCSE point score ${ }^{8}$ of the students who achieved that qualification. Figure 1 shows the distribution of the scores in each qualification in order of selectivity 9 .

It is evident that there are substantial differences in the 'selectivity' of each qualification with the median scores of students achieving the most highly-ranked qualifications being considerably higher than those of the students achieving the lowest ranked ones. In addition, the difference between the median GCSE scores of students achieving vocational and academic qualifications is also notable. We would expect to see this difference for Level 1 and Level 2 vocational qualifications, given that the students pursuing these qualifications are usually those who have not done well enough in their GCSEs and presumably could

\footnotetext{
${ }^{6}$ The Russell Group consists of the following 24 institutions: Birmingham, Bristol, Cambridge, Cardiff, Durham, Edinburgh, Exeter, Glasgow, Imperial College, King's College London, Leeds, Liverpool, London School of Economics, Manchester, Newcastle, Nottingham, Oxford, Queen Mary College London, Queen's Belfast, Sheffield, Southampton, University College London, Warwick, and York. These institutions are research intensive and committed to provide an outstanding teaching and learning experience to their students. More information about the Russell Group guidance can be found by accessing their web-page at https://russellgroup.ac.uk

${ }^{7}$ According to the Russell-Group university guidance the A level subjects which are most often preferred or required, called 'facilitating subjects', include the following: Mathematics and Further Mathematics, English Literature, Physics, Biology, Chemistry, Geography, History and Languages. The study uses the taxonomy provided by Dilnot (2018) to distinguish between two groups: facilitating and non-facilitating A levels. Dilnot (2016) suggested that one of the reasons why students from lower socio-economic backgrounds are under-represented at high status universities is because of differential choice of A levels. These differentials, though, substantially disappeared when the author accounted for age 16 test scores. In any case, A levels in facilitating subjects are more valued by institutions and it is considered important to distinguish between the facilitating and the non-facilitating subjects.

${ }^{8}$ The GCSE point score is calculated from the total number of GCSE points of the students' best eight subjects including Maths and English.

${ }^{9}$ The qualifications have been implicitly ranked in ascending order representing the selectivity of each, based on the median GCSE point score of the students achieving each qualification.
} 
not pursue a Level 3 qualification. On the other hand, especially given that Hupkau et al. (2017) found that A levels and vocational qualifications at Level 3 are equally strong predictors of staying on in education up to the age of 18 and achieving a Level 3 qualification before the age of 20, we would not expect this difference in the median exam scores of students achieving Level 3 vocational qualifications from those achieving Level 3 academic qualifications.

Figure 1: Measure of qualification's selectivity based on median standardised GCSE scores of students achieving that qualification

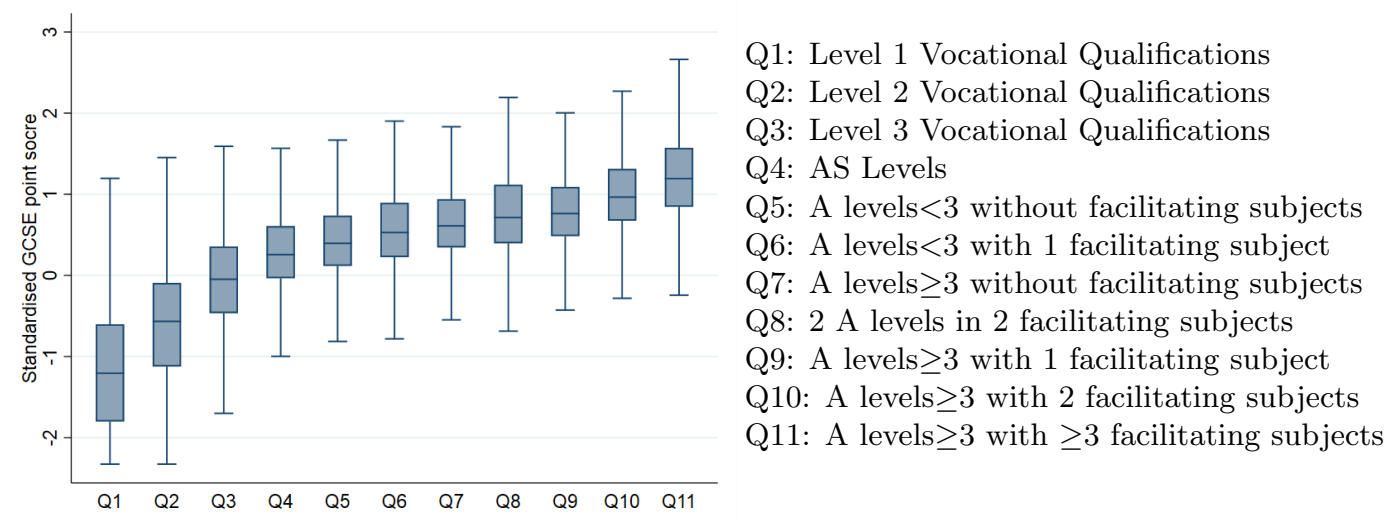

Note: The box plots display the full range of variation of GCSE scores of students achieving each qualification with the upper and lower lines of the box representing the $75^{t h}$ and $25^{t h}$ percentiles of GCSE scores respectively, the middle line representing the median GCSE scores and the top and bottom extending lines the range.

\section{Step 2: Creation of the Academic Matching Index}

The study introduces a new continuous measure of student-qualification match in postcompulsory upper-secondary education calculated using the following three steps:

1. Individual ability distribution: The ability of each student is identified based on their position in the standardised distribution of the GCSE point score.

2. Qualification quality distribution: The selectivity of each upper-secondary qualification (Q1-Q11) is identified in a distribution of qualification quality based on the standardised median GCSE point score of students achieving that qualification.

3. Academic matching index: The student's position on the individual ability distribution is subtracted from the position of their course in the qualification quality distribution. In other words, the academic matching index subtracts the standardised GCSE point score of the individual from the median GCSE point score of the students who achieved the same qualification as the individual. In mathematical terms the equation used is: $\operatorname{Match}_{i, q}=\operatorname{med}\left(z g c s e_{q}\right)-z g c s e_{i}$.

The result is a continuous measure of academic match for each student in upper-secondary 
education. The distribution of this measure is illustrated in Figure 2. The matching index presents the distance of each student's standardised GCSE point score from the median standardised GCSE point score of the students' achieving their chosen qualification. This method benefits from being able to identify low and high levels of undermatch or overmatch on a standardised scale ranging from -4.66 to 3.52 standard deviations. A negative value on the matching index implies that the student is studying for a qualification that is lower on the qualification quality distribution than they are on the individual ability distribution (in other words, the student is undermatched). A positive value implies that the student is studying for a qualification that is higher on the qualification quality distribution than they are (in other words, the student is overmatched). Finally, for students who scored close to zero on the matching index it is indicated that their qualification quality is matching their ability level. If a student is exactly average on the individual ability distribution then the student is matched if their chosen qualification is exactly average in the qualifications' quality distribution. If the student is one standard deviation above the average in the ability distribution and they choose a qualification which is exactly average in the quality distribution, then they are undermatched by one standard deviation ${ }^{10}$.

Figure 2: Measure of student-qualification match based on GCSE point score

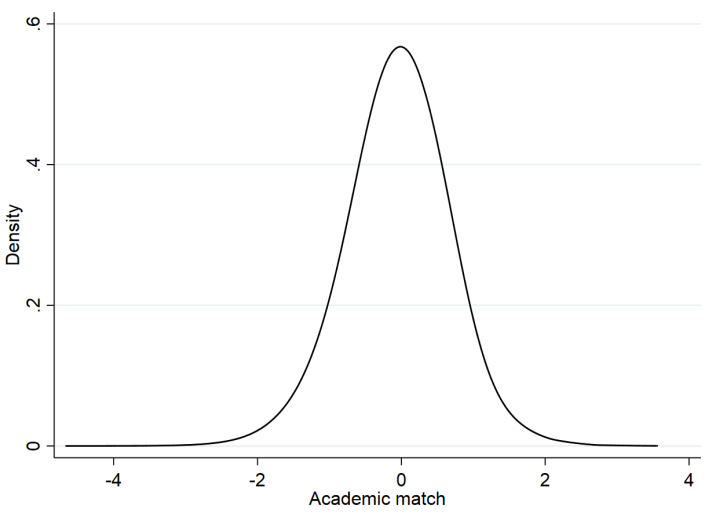

The basis of this continuous measure of academic match is the idea that a student should be broadly comparable (matched) with their equally able peers in terms of educational attainment (Campbell et al., 2019). This idea has been supported in all studies in academic match in HE reviewed in Section 3 and a similar approach has been applied in this study for upper-secondary qualifications. Especially for upper-secondary qualifications, though, it should be recognised that such definitions of qualification quality are somewhat

\footnotetext{
${ }^{10}$ As will be explained later on, when having to categorise students as being undermatched, matched and overmatched for some of the analyses that follow, the cut-off point has been relaxed and students have been considered as matched if they scored between half a standard deviation above or below zero on the standardised matching index.
} 
subjective particularly given that the scope of A levels and AS levels differs from that of vocational qualifications. The median GCSE point score which is used as an indicator of qualification rank is not necessarily the most important characteristic or the only important in determining the quality of the qualification.

However, obtaining A levels, especially in facilitating subjects, provides a greater opportunity to enter a high status HE institution which is associated with a higher wage return (Chowdry et al., 2013). It is also suggested that vocational education prevents drop-out rates, presumably of the least able students who are likely to be more vulnerable to dropouts as well as reducing unemployment rates of young people. It is therefore argued that the points-based measure of a qualification's rank is a good proxy for the nature of the upper-secondary qualification being studied by a particular student which in turn will have long run economic implications for these individuals.

\section{Key Variable}

\section{Socio-economic background}

The key variable in this study is the socio-economic group the student belongs to. Ideally for this study we would want a detailed measure of the student's socio-economic background such as family income, parental occupation and education. Unfortunately, the administrative data used in this study do not contain such measures of socio-economic background. Instead, the study follows the approach of Chowdry et al. (2013) to construct a socio-economic index which combines both individual and neighbourhood level measures of socio-economic background. The individual measure of socio-economic background is collected from information concerning whether the student was eligible for FSM at age 16 which is basically an indicator of whether the student is from a household which receives state benefits (around 15\% of students). The FSM eligibility depends on applying for state benefits and is therefore not a sufficient measure for all students. Also, we need to be able to identify students who are from the highest and the lowest socio-economic groups and the FSM indicator would not do so. For that reason, a detailed set of neighbourhood variables has been used which are available at the Lower Super Output Area (LSOA), a geographic neighbourhood comprising of around 700 households or around 1,500 individuals.

The socio-economic index consists of:

1. Free school meal eligibility (2006) 
2. Index of Multiple Deprivation $(2007)^{11}$

3. Three area-based measures indicating the proportion of neighbours that:

(a) Work in managerial and professional occupation (2001)

(b) Hold a Level 3 qualification or above (2001)

(c) Are home owners (2001)

These measures have been combined using principal components analysis ( $P C A$ ) to create a standardised index using the whole population of state-school students including those who did not participate in post-compulsory education. Therefore, throughout this paper socio-economic background refers to the socio-economic position of a student relative to the whole school-cohort population for whom information was available. The sample has been then divided into five socio-economic quintiles on the basis of this index. Figure 3 shows the distribution of academic match of students in the highest and lowest socioeconomic quintile compared to the distribution of academic match of the total analytical sample. It is illustrated that students from the lowest socio-economic quintile are less well matched to their chosen upper-secondary qualification compared to students from the highest socio-economic quintile.

Figure 3: Academic match of highest and lowest SES students

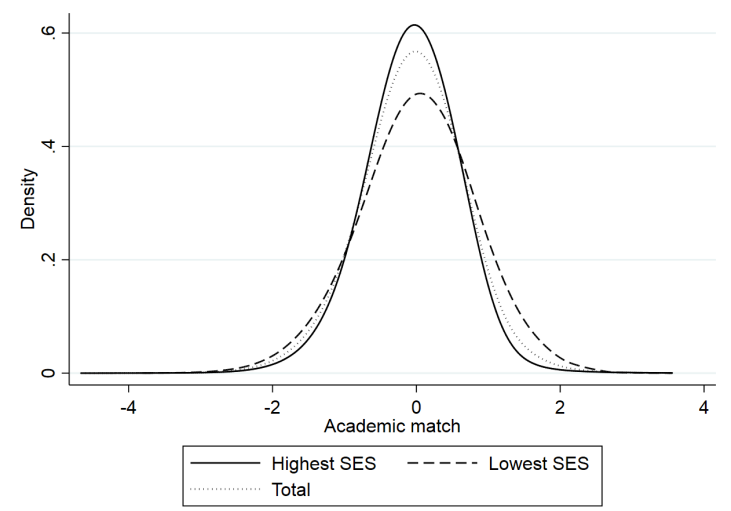

\section{Control Variables}

\section{Measures of prior attainment}

The measures of prior attainment come from school tests taken at the age of 11 and teacher assessments at the age of 14 reflecting the students' attainment in three core subjects, Maths, Science and English. The average age 11 test scores (average attainment

\footnotetext{
${ }^{11}$ The Index of Multiple Deprivation ranks all LSOAs in England from least to most deprived, based on income, employment, education, health, crime, barriers to housing and services, and living environment.
} 
in KS2 Maths, Science and English) and average age 14 level scores (average level achieved in KS3 Maths, Science and English) are used as indicators of prior attainment.

In addition to controlling for prior attainment at age 11 and 14, the students' performance in GCSE exams (in about 10 subjects) is expected to have a significant impact on students' academic match as well as a strong correlation with important variables such as socio-economic background. Given how the matching index is constructed, including the individual GCSE point score in the set of prior attainment controls has both its benefits and limitations. Regressing the matching index $\left(\operatorname{med}\left(z g c s e_{q}\right)-z g c s e_{i}\right)$ against individual score $\left(z g c s e_{i}\right)$ will show the impact of socio-economic background (and other covariates) on upper-secondary qualification rank, conditional on individual GCSE point score, rather than the effect on match distance. On the other hand, not controlling for individual GCSE point score would produce biased results on any variable strongly correlated with it, including socio-economic background.

Figure 4 shows the distribution of academic match of students in the highest and lowest socio-economic quintile as well as that of the total sample across the individual GCSE point score distribution. There are two important points to be derived from Figure 4. First, the relative position of the two distributions (Highest SES and Lowest SES) reflects what has been also observed in Figure 3, that students from the lowest socio-economic quintile are less highly matched to their upper-secondary qualification across the GCSE point score distribution compared to students from the highest socio-economic quintile.

The second major point illustrated in Figure 4 is that academic undermatch is more prevalent among the high achieving students. This is not so surprising as low achieving students, with few GCSE points, could not undermatch since there would be no course whose median score would be at a lower position in the distribution. Therefore, we should expect that the socio-economic effect in academic match will vary significantly across students of differing ability levels and we can expect that the gap will be greater among high achieving students.

In order to address what is discussed above the estimations that follow combine both regressions with individual GCSE point score included in the set of prior attainment controls as well as heterogeneous analyses, splitting the sample into ability quintiles. In the latter, individual GCSE point score is not controlled for. All exam and test scores have been standardised to have a mean of 0 and a standard deviation of 1 . The standardisation 
of these variables reflects the ability position of post-compulsory education participants compared to the total cohort of students.

Figure 4: Academic match across the GCSE point score distribution

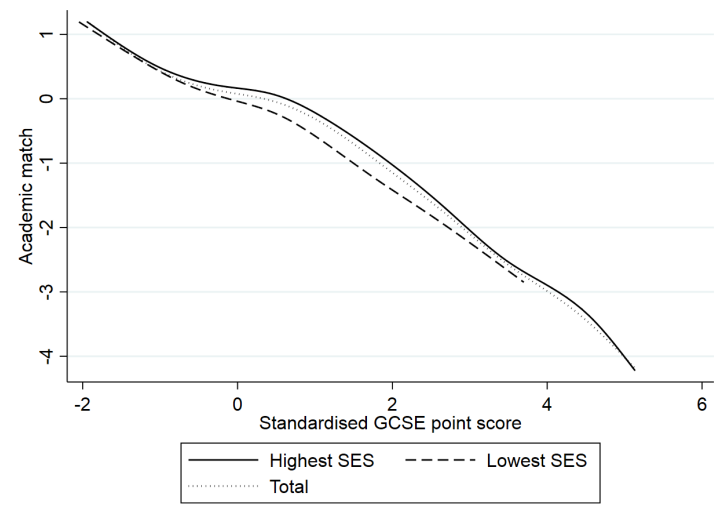

\section{Other individual and school characteristics}

The study controls for basic demographics including gender and ethnicity recorded at age 16. Most highly ranked upper-secondary courses require five A*-C GCSEs including Maths and English and therefore an indicator of whether the student achieved this threshold is also included. Finally, attempting to control for school quality, peer effects and unobserved differences between students the study applies school fixed effects taking into account the secondary school attended. It should be mentioned that although the school an individual attends is likely to be an important determinant of academic match we should be very cautious about the interpretation of the results in the presence of these fixed effects for reasons that will be explained in Section 5 .

\subsection{Descriptive Statistics}

The descriptive statistics of the analytical sample by quintile of socio-economic group are provided in Appendix A. It is indicated that there is a significant difference by socioeconomic group in the proportion of students leaving compulsory schooling having achieved five A*-C GCSEs including Maths and English with $69 \%$ of the students from the highest socio-economic group having achieved this threshold compared to just $29 \%$ of students from the lowest socio-economic group. Also, there are substantial differences in the average test scores of students from differing socio-economic groups with the achievements of the poorest students being significantly lower than those of the students from the highest socioeconomic group both at school examinations at ages 11 and 14 and high-stake national examinations at age 16. It is also worth noting that students from ethnic minorities tend 
to be over-represented in the lowest socio-economic groups. Further, it can be observed that there are substantial differences in the post-compulsory qualifications the students from different socio-economic groups achieved. It is evident that the most highly ranked qualifications are much more prominent for students in the highest socio-economic group as $39 \%$ of the students achieved the three most highly ranked qualifications, compared to only $10 \%$ of the students from the lowest socio-economic group.

\subsection{Where are the undermatched and overmatched students?}

The chloropleth map in Figure 5 shows the proportion of undermatched and overmatched students in each LAD of England. The darker is the LAD's colouring the higher the proportion of undermatched students living in it. The map demonstrates that there are several critical masses of undermatched students in mostly rural areas in Durham, Leicestershire and in the South West (see Figure 6 for information on rural and urban areas). On the other hand, critical masses of overmatched students can be observed in non-rural areas in Greater London and the South East including Surrey and Oxfordshire. The other critical masses of overmatched students are more scattered but some areas in South Cumbria and North Yorkshire can be picked out.

The incentives of students to acquire qualifications might partly be due to local labour market conditions or due to highly or poorly educated parents being concentrated in specific areas. To enlighten on this matter, the chloropleth map in Figure 7 illustrates the proportion of each district's residents who hold at least a Level 4 Qualification (equivalent to a Certificate of HE). Similarly, the chloropleth map in Figure 8 illustrates the proportion of residents aged 16-24 who claim job seekers allowance (in other words the rate of youth unemployment). It is observed that there are some significant masses of highly educated residents and low proportions of claimants in Greater London, the South East and in South Cumbria and North Yorkshire. In districts such as Durham, Leicestershire and Cornwall, where significant masses of undermatched students have been noticed, a high unemployment rate and a poorly educated population are observed. 
Figure 5: Proportion of academic match in each LAD
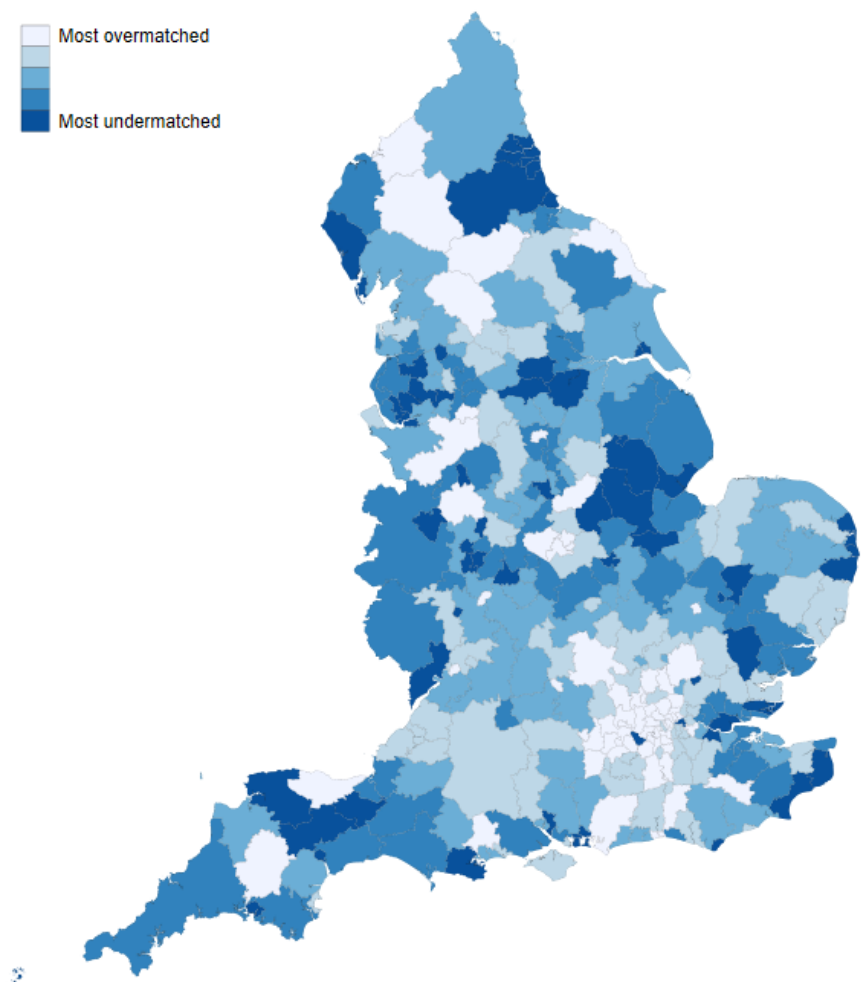

Figure 6: Urban and Rural LADs

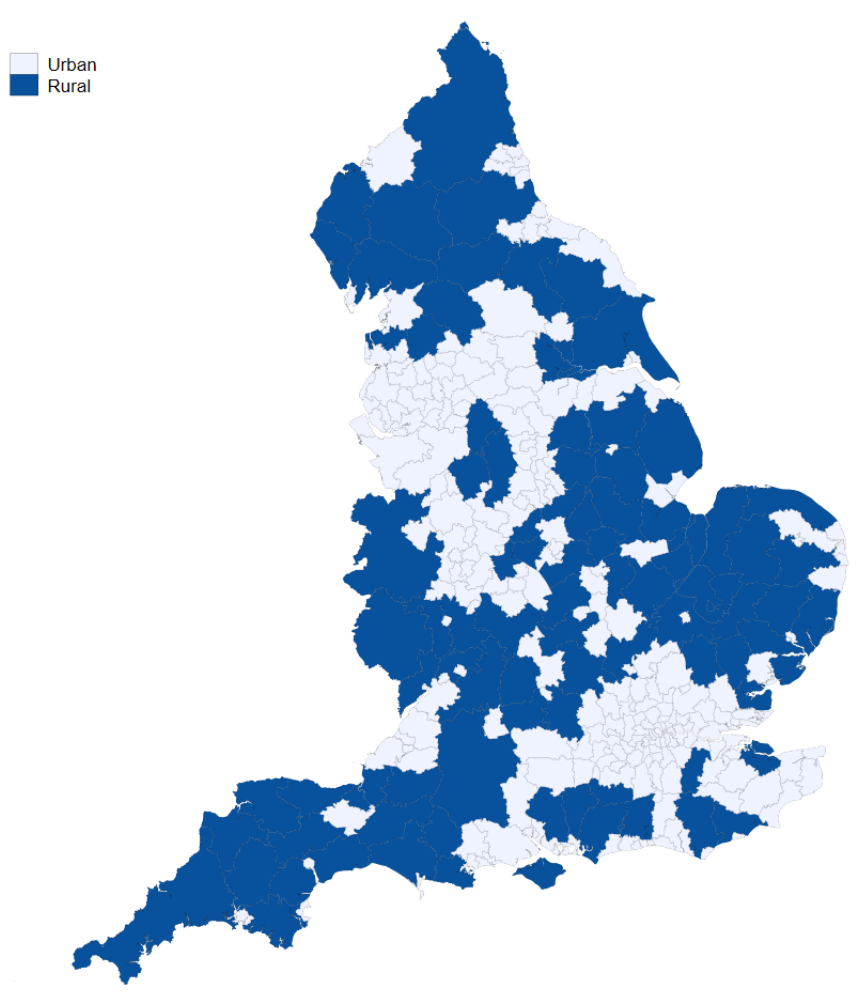


Figure 7: Proportion of population with a Level 4 Qualification or above in each LAD

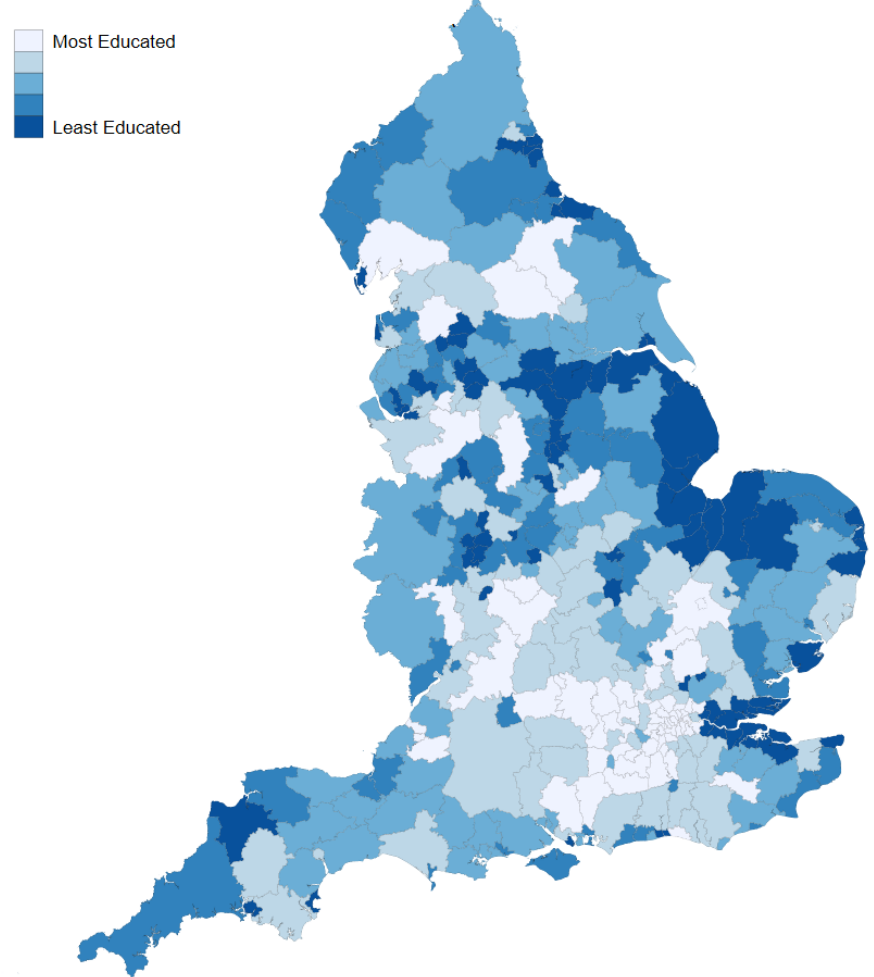

Figure 8: Proportion of 16-24 claimants in each LAD
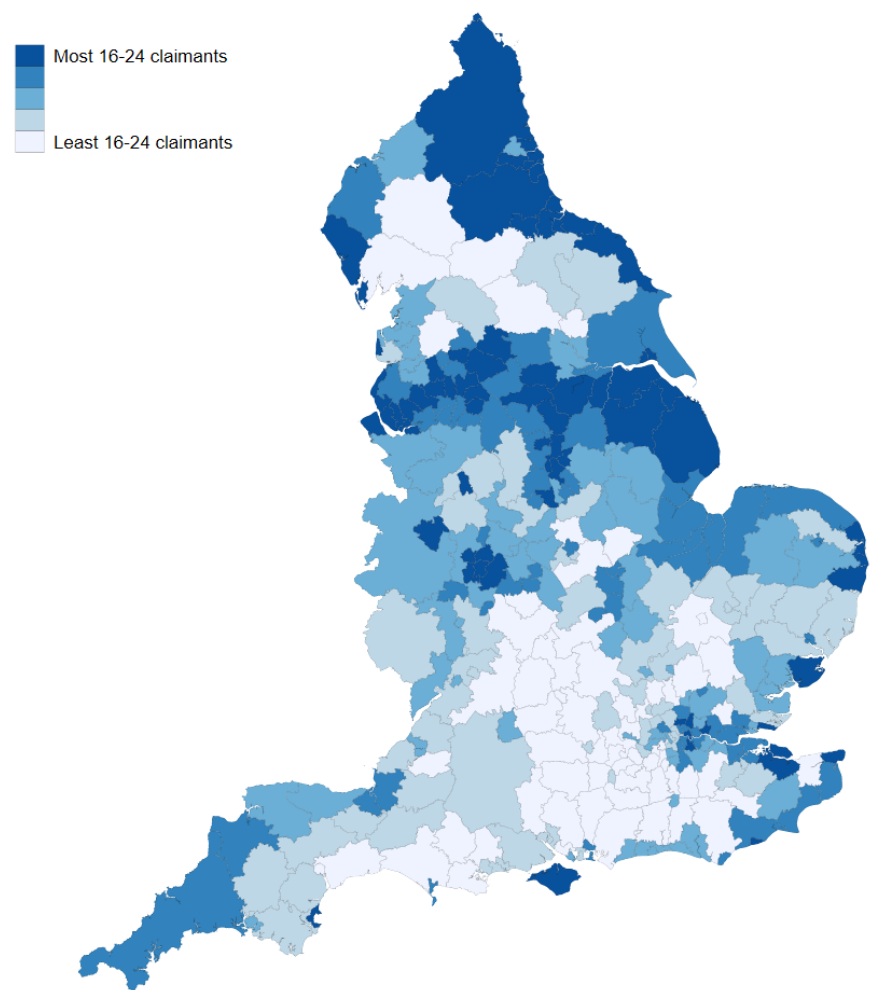


\section{Methodology}

The following model has been estimated for the $i^{t h}$ individual who attended secondary school $s$ and achieved upper-secondary qualification $q$ using ordinary least squares (OLS) regression with robust standard errors clustered at the secondary school level:

$$
M_{i, s, q}^{*}=\beta_{0}+\sum_{j=2}^{5} \beta_{j}\left(S E S_{i}=j\right)+\delta^{\bullet} A_{i}^{\prime}+\gamma^{\bullet} X_{i}^{\prime}+\eta_{s}+\epsilon_{i, s, q}
$$

where the variables are:

- $M_{i, s, q}^{*}$ : the measure of student-qualification match for individual $i$, who attended secondary school $s$ and achieved upper-secondary qualification $q$

- $S E S_{i}=j$ : the SES quintile each individual belongs to

- $A_{i}^{\prime}$ : a vector of prior educational attainment of individual $i$ at age 11,14 and 16

- $X_{i}^{\prime}$ : a vector of demographic characteristics for individual $i$

- $\eta_{s}$ : the secondary school fixed effects

- $\epsilon_{i, s, q}$ : the error component clustered at the secondary school level

The relationship between socio-economic background and academic match has been examined by estimating the above equation sequentially. In the first specification no additional covariates are included other than socio-economic status. In the second specification a set of prior attainment controls at ages 11, 14 and $16^{12}$ are introduced for each student. In the third specification several demographic characteristics are added and the final specification includes secondary school fixed effects. The coefficients in this final specification should be interpreted with caution. Although school characteristics might be important determinants of the post-compulsory education pathways each individual chooses to follow, the school a student attends is often determined by residential location and is therefore partly an outcome of socio-economic background ${ }^{13}$. As a consequence, the school fixed effects are likely to absorb some of the variation which should be attributed to socio-economic background and the resulting coefficients are biased downward.

\footnotetext{
${ }^{12}$ As explained above, we should be cautious about the inclusion of controls for prior attainment at age 16. For that reason one additional investigation has been carried out where instead of controlling for individual GCSE point score the sample is divided into ability quintiles, based on students' performance at age 16 exams. This additional analysis will allow us to examine whether any identified socio-economic gap varies across ability levels.

${ }^{13}$ Gibbons and Machin (2003) indicated this relationship for primary schools in England by showing that a one percentage point increase in the neighbourhood proportion of children reaching the governmentspecified target grade pushes up neighbourhood property prices by $0.67 \%$.
} 


\section{Empirical Results}

\subsection{Main findings}

The main findings identifying the relationship between socio-economic background (hereafter SES) and academic match are reported in Table 3. The first column shows the raw SES differences in academic match. Then, the extent to which these gaps can be accounted for by differences in other observable individual characteristics has been examined, including prior attainment at ages 11, 14 and 16 in column 2, basic demographics in column 3 and the secondary school the young person attended in column 4 .

The findings reflect large differences in academic match by SES group. The first column showing the raw SES gradient in academic match is not very informative in providing insights about the direction of the relationship as the estimated coefficients take both negative and positive values and are even statistically insignificant for one of the SES groups. After accounting for prior attainment in column 2 the results start to become clear, showing a large and significant SES gradient in academic match. Since the matching index is negative when the students are undermatched, close to zero when they are matched and positive when they are overmatched, the negative and significant coefficients reported for students from all SES groups mean that they rank lower on the matching index than the students from the highest SES group ${ }^{14}$. For example, students who come from the lowest SES group are found to average 0.16 standard deviations (s.d.) lower on the matching index compared to the students from the highest SES group. When introducing basic demographic characteristics in column 3 the SES gap observed in column 2 remains very similar. These findings suggest that differences in demographics from students of different SES groups provide only a minor explanation for why students from lower SES groups are less likely to rank higher on the matching index.

The final specification presented in column 4 adds secondary school fixed effects and the estimates, although decreasing substantially to about half, do not loose their precision. As mentioned above, the coefficients in this specification are likely to be downward biased but still, they do indicate that there is a significant relationship between SES and academic match which exists even between students of the same school.

To further understand these findings, it is important to examine how the identified SES

\footnotetext{
${ }^{14}$ The negative coefficients do not necessarily indicate that the students are undermatched. They might still be overmatched to their upper-secondary qualification, just less than students from the Highest SES group.
} 
gap varies across students of differing ability levels. In the section that follows the sample is divided into ability quintiles based on their performance in GCSE exams. The outcome of this analysis is discussed in Subsection 6.2. Further, the findings suggest that the secondary school attended absorbs a significant amount of the SES effect in academic match and therefore it would be very informative if we were able to disentangle between which features of the school are important in influencing academic match. Unfortunately, the available data do not allow such an investigation but, having information on several school characteristics, Subsection 6.3 attempts to provide an insight with regards to the large school gradient observed in the final specification.

The estimates on the effect of the other covariates are also of interest. The results suggest a significant gap between boys and girls with girls scoring about 0.04 s.d. higher on the matching index compared to boys in column 3 and about 0.03 s.d. higher in column 4 , after applying school fixed effects. Also, the findings suggest a non-trivial impact of ethnic background with White students consistently found to score lower on the matching index compared to students from ethnic minority backgrounds.

In summary, the findings suggest that students from lower SES groups are more likely to score lower on the matching index compared to their more advantaged peers even when considering their prior attainment, demographics and secondary school attended. These findings are in line with the findings of other studies examining academic match in $\mathrm{HE}$ (Campbell et al., 2019; Hoxby and Avery, 2012; Smith et al., 2013) and provide evidence that academic undermatch occurs before entrance to university.

\subsection{Socio-economic effect in academic match across differing levels of ability}

Table 4 presents the results of the SES gap in academic match across ability quintiles based on the total GCSE point score of each individual ${ }^{15}$. Recall that in this analysis the individual GCSE point score is not included in the set of prior attainment controls.

Focusing on the most preferred specification (column 3) it can be observed that the SES gap becomes far more prominent across the highest achieving students. While the lowest achieving students from the lowest SES are found to average (surprisingly) about 0.01 s.d.

\footnotetext{
${ }^{15}$ As a robustness check the sample has been also divided by the number of A*-C GCSEs achieved $(0$ A*-C GCSEs, $1 \mathrm{~A}^{*}$-C GCSE, $2 \mathrm{~A}^{*}$-C GCSEs, $3 \mathrm{~A}^{*}$-C GCSEs, $4 \mathrm{~A}^{*}$-C GCSEs, 5 or more A*-C GCSEs without Maths and English, 5 or more A*-C GCSE including Maths and English) and the results remained qualitatively unchanged.
} 
higher on the matching index compared to the students from the highest SES, the highest achieving students from the lowest SES are found to average about 0.27 s.d. lower. The findings, therefore, suggest that among low ability students, SES makes little difference on students' match to upper-secondary qualifications while, on the other hand, among the high achieving students it is those from disadvantaged backgrounds who fail to match to their qualifications either by not seeing, understanding or wanting the opportunity that their ability opens for them.

The SES gap that is observed among high achieving students is non-trivial and these findings suggest that the SES effect works more by keeping high ability disadvantaged students down rather than keeping low ability advantaged students up. While this gap is substantially reduced when applying school fixed effects in column 4 the estimations still suggest that this gap exists even within schools. Interestingly, the SES gradient that is absorbed when school fixed effects are applied in the final specification increases dramatically among the highest achieving students. The findings suggest that among the highest achieving students almost $80 \%$ of the identified gap can be explained by differences in the schools that young individuals from differing backgrounds attend.

Comparing to the findings of Campbell et al. (2019) for students in HE, the SES gradient observed in academic match among the highest achieving students is of similar magnitude. For example, Campbell et al. (2019) reported that students from the lowest SES quintile average about 0.30 s.d. lower on the matching index compared to students from the highest SES quintile, which is just about 0.03 s.d. greater than what is observed in uppersecondary education.

\subsection{Analysis on school composition of undermatched, matched and over- matched students}

The secondary school each student attended has been identified to explain a significant proportion of the SES gap in academic match. For this reason I take this investigation further and examine the differences in the schools that the undermatched, matched and overmatched students attended. The matching index suggests that students who are exactly average on the ability distribution should be matched to exactly average qualifications on the qualification-quality distribution. In this analysis, the students who matched have been considered those who scored between 0.5 s.d. below or above zero on the matching index. Therefore, the undermatched students are those who scored less than -0.5 s.d. on 
the matching index while the students who scored more than 0.5 s.d. on the matching index have been considered overmatched. In the sample, about $63 \%$ of the students are matched, $21 \%$ are undermatched and $16 \%$ are overmatched.

Table 5 presents the average school characteristics of the undermatched, matched and overmatched students by SES quintile. The available data do not allow us to disentangle the relative causality of these factors in producing academic mismatch but comparing means in this way provides an indication of how the environments of the students might be different. All the school characteristics are based on the secondary school the student attended at age 16 .

The data suggest large differences in the school composition of students from different SES. The students from the lowest SES group are found in schools with higher proportions of peers who come from a disadvantaged background. For example students from the lowest SES group attend schools where the percentage of students with FSM eligibility is about $23 \%-25 \%$ while this proportion is decreased to just $7 \%-9 \%$ for students from the highest SES group. Further, students from higher SES groups attend schools with a greater proportion of high achieving peers, as identified from the percentage of students achieving 5 or more A*-C GCSEs including Maths and English, compared to students from lower SES groups. Also, students from lower SES groups are more likely to be found in schools with higher proportions of students coming from a non-White background.

Comparing within SES groups the observed differences between the undermatched, matched and overmatched students are less stark. However, it can be still observed that within all SES groups there tends to be a higher proportion of matched students in schools with higher proportions of high achieving students. Also, students who are both undermatched and overmatched to their qualification tend to be more apparent in schools with a greater proportion of disadvantaged students.

Table 6 explores the influence of these school characteristics in more detail by regressing the full set of SES indicators, prior attainment and demographic controls augmented with these school characteristics on the matching index. Differences between the environments of the undermatched, matched and overmatched students are still apparent. Students in schools with higher proportions of peers who are eligible for a FSM and who are from White-British ethnicities are less likely to score higher on the matching index while students in a school with higher proportions of high achieving peers are more likely to score 
higher. Table 7 shows the same information while splitting the sample into ability quintiles based on individual GCSE point score, instead of controlling for it. Interestingly, the negative effect of having more disadvantaged peers in academic match becomes greater in magnitude among the highest achieving students which is consistent with the main findings in Table 4. Similarly, the positive relationship between academic match and having a greater proportion of high achieving peers is stronger among the highest achieving students.

\subsection{Does LAD's characteristics impact academic match?}

This subsection investigates the impact of LAD's characteristics in academic match regressing the regional characteristics, discussed in Subsection 4.5, on the academic matching index while controlling for SES, prior attainment and demographics ${ }^{16}$. The results from this analysis can be found in Table 8. The findings support what has been observed in the chloropleth maps. The students residing in urban areas are found to rank higher on the matching index compared to students residing in rural areas. Also, students who are residents in LADs which have a greater proportion of well educated residents are found to rank higher on the matching index. For example, a $10 \%$ increase in a LAD's residents who have a Level 4 Qualification or above is associated with scoring about 0.03 s.d. higher on the matching index. Finally, students residing in areas with a greater proportion of youth unemployment are observed to rank lower on the matching index. Precisely, a $10 \%$ increase in the proportion of 16-24 claimants is associated with scoring about 0.06 s.d. lower on the matching index.

\subsection{Income returns to academic assortative matching in upper-secondary education}

This subsection estimates the returns to being academically assortatively matched using the method that has been suggested by Campbell et al. (2019) for HE and has been applied in this study for post-compulsory upper-secondary education. Making use of newly available data from HMRC tax records ${ }^{17}$, I examine the effect of scoring higher on the matching index on the log daily income of students at age 25. Specifically, employer

\footnotetext{
${ }^{16} \mathrm{I}$ also run the same regressions while splitting the sample into ability quintiles based on individual GCSE point score, rather than controlling for it. The results follow the same pattern as the one observed for school composition characteristics presented in Table 7.

${ }^{17}$ The matching was kindly undertaken by officials at the Department for Education, with the matched anonymised data set provided to us.
} 
return forms (P14, P45 and P60) available in the dataset provide accurate information on earnings during the year (total annual pay in the 2015 tax year) and start and end date of periods of employment, for those who change employers during the year. These data were used to create a daily earnings measure, which is preferable to an annual earnings measure since it does not depend on the number of days worked per year, which will vary endogenously across individuals (McIntosh and Morris, 2018). Unfortunately no information on hours of work is included in the tax data, and so an hourly wage measure could not be obtained.

Further, the available data lack important information concerning when each individual entered the labour market. For example some of the students could enter the labour market after completing upper-secondary education when aged 18-19 and their income at age 25 includes 6-7 years of work experience. Other students studying for an undergraduate degree usually would enter the labour market at age 20-21 and those proceeding to a postgraduate degree would enter the labour market the earliest at age 21-22 and would have only 3-4 years of experience by age 25 . I try to eliminate this bias by estimating separate models for university and non-university participants ${ }^{18}$. It should be acknowledged that those students who go to university are more likely to be higher achievers at age 16 and therefore more likely to be undermatched because of the mechanical relationship between high attainment at age 16 and chance of being undermatched. Therefore, in the analyses that follow it is vital to control for individual GCSE point score to avoid biased results with regards to income returns to academic match which should have been instead attributed to attainment at age 16. In any case, identifying a causal effect of being matched in uppersecondary education on future returns is beyond the scope of this study. The analysis attempts to indicate the direction of this relationship rather than to assign a causality to it.

The outcome of this analysis is presented in Table 9. Due to the well-established differences in returns to education by gender in addition to the aggregated sample results the results are also presented separately for boys and girls. The results indicate a positive relationship between log daily income at age 25 and scoring higher on the matching index, especially for non-university participants. For example, the aggregated results for students who did not attend a HE course indicate that scoring 1 s.d. higher on the matching index is associated

\footnotetext{
${ }^{18} \mathrm{~A}$ university participant is a student who has attended a course in any UK HE institution. The available data do not provide any additional information regarding the nature of the course or whether the individual has completed the course.
} 
with higher $\log$ daily income of 0.09 points, which is approximately equal to a $9 \%$ increase in actual income. Comparing between boys and girls, the returns to academic assortative matching are much more apparent for girls. For university participants, scoring a 1 s.d. higher on the matching index is associated with about a $9 \%$ increase in log daily income at age 25 for girls while for boys it is associated with a $2 \%$ decrease on log daily income. For non-university participants the effect is still notably higher for girls. Girls who matched 1 s.d. higher on the matching index are found to earn about $18 \%$ more compared to boys who earned about $2 \%$ more.

The results of this analysis for the other variables are also of interest and are therefore presented in Appendix B. The main findings of this paper suggested that girls and students from ethnic minorities were the ones identified to score higher on the matching index. The current analysis established the positive relationship between income and academic assortative matching. It is interesting and disappointing, hence, to see that there is a significant gender and ethnic gap on income returns with girls and individuals from ethnic minority backgrounds earning significantly less, although being the ones who scored higher on the matching index (though that is held constant in this analysis). Especially for nonuniversity participants the gender gap is non-trivial. Girls are found to earn $36 \%$ less than boys. Also non-university participating Black students are earning $24 \%$ less than non-university participating White students.

Evidently, these findings indicate a significant advantage of scoring higher on the matching index on income returns, at least at early ages. Analysing income returns using the matching index assumes that its effect is linear while it could be that it is being matched (scoring in the middle of the index) that has positive income returns rather than being both overmatched or undermatched. On the other hand, it might be the case that it is the overmatched students that are driving these positive returns on income. For that reason, one additional analysis has been carried out to enlighten with regards to this matter. The matching index has been recoded to take a value of 0 for all the individuals who scored at or above -0.5 (all matched and overmatched students). This variable will show the income returns of being 1 s.d. less undermatched. Then a second variable has been created for the overmatched students, recoding the matching index to take a value of 0 for all students who scored at or below 0.5 (all the matched and undermatched students). The coefficients of this variable will indicate the income returns of being 1 s.d. more overmatched. As before separate results are presented for university and non-university participants and for 
girls and boys.

The outcome of this analysis is presented in Table 10. The effect of being less undermatched on labour market income returns is now more apparent and still considerably greater in magnitude for girls than boys. Non-university participating girls who were 1 s.d. less undermatched are found to earn about $17 \%$ more. For university participating girls this effect decreases to $10 \%$ but it still remains positive and significant. The effect of academic undermatch has also become more apparent for boys although it is smaller in magnitude compared to girls. University participating boys who were 1 s.d. less undermatched in their upper-secondary qualification earned $3 \%$ more at age 25 while non-university participants earned about $5 \%$ more.

Turning to the effect of being more overmatched, in order to clarify whether the earlier findings are driven by students who are overmatched, we can see that this is not the case. For university participating students, more overmatching is associated with a negative daily income return. For non-university participants, there is a positive return to being more overmatched but it is much smaller than the effect of being less undermatched. One possible explanation that we could assign to this outcome is that students pursuing qualifications which are beyond their academic credentials could be achieving them with a very low grade.

The outcome of this analysis highlights the importance of being academically assortatively matched, establishing the strong and positive relationship of being matched and labour market income returns. The results indicate that this positive effect is not driven by students overmatching to qualifications but that it is actually an outcome of being academically matched. This is evident from the fact that while being less undermatched has a significant positive impact on labour market returns, being more overmatched does not have an equally positive effect.

In order to convince on the robustness of these findings there is one potential parameter that needs to be considered. Given how the matching index is constructed, Match $_{i, q}=$ $\operatorname{med}\left(z g c s e_{q}\right)-z g c s e_{i}$, when controlling for individual GCSE point score in the estimated models it is possible that the positive coefficients observed in Table 9, instead of reflecting positive income returns to scoring higher on the matching index rather reflect positive income returns to achieving a higher upper-secondary qualification which would thus result in a higher score on the matching index, given that the individual GCSE point score is 
kept constant. Therefore, one additional analysis is carried out to examine the robustness of the results.

A categorical variable has been constructed identifying whether the individual is matched (scoring between -0.5 s.d. and 0.5 s.d. on the matching index), undermatched (scoring below -0.5 s.d. on the matching index) or overmatched (scoring above 0.5 s.d. on the matching index) and the continuous measure of academic match has been replaced with this new categorical variable. This robustness check is important as it allows us to control for both the individual GCSE point score and the upper-secondary qualification achieved by the individual and therefore any observed differences in the estimated coefficients will reflect the effect of being matched rather than being undermatched and being matched rather than being overmatched while keeping these two important parameters constant. The outcome of this analysis is presented in Appendix C. The results show a negative log income return to being both overmatched and undermatched compared to matched individuals suggesting the robustness of the main estimations.

\section{Conclusion}

The study uncovers a significant socio-economic gap in academic match among English students in upper-secondary post-compulsory education. Students from lower socio-economic backgrounds achieve less highly ranked qualifications compared to their similarly attaining but more advantaged peers. This gap is identified to be greater among the highest achieving students suggesting that socio-economic inequality works more by keeping high ability disadvantaged students down than keeping low ability advantaged students up. Further, it is revealed that students from low socio-economic backgrounds attend disadvantaged schools with significantly lower proportions of high achieving peers and greater proportions of disadvantaged peers and that among the highest achieving students $80 \%$ of the identified socio-economic gap can be explained by such differences in the schools that young people from differing backgrounds attend. This finding substantially means that factors associated with secondary school attended such as peers, teacher quality, parental sorting and information provided by the school are likely to be the key drivers for improving the academic match of students in post-compulsory qualifications.

In addition, the study identifies that geographical factors are also strong predictors of academic match with the most undermatched students being found in mostly rural areas 
with greater proportions of youth unemployment and lower proportions of highly educated residents. It is also demonstrated that there is a significant labour market cost of being undermatched, especially for non-university participating girls who are found to earn $17 \%$ more at age 25 when being 1 s.d. less undermatched.

Hupkau et al. (2017) identified that students undertaking vocational qualifications at Level 2 or below are much more likely to be from disadvantaged family backgrounds than those undertaking higher levels of qualifications and that generally they do not have the prerequisites to start their post-compulsory education at a higher level. This study reveals that disadvantaged students, even if qualified to study for a higher level qualification, are still more likely to undermatch in less highly ranked qualifications. There are important policy implications to be drawn from these findings. Policy-makers interested in social mobility should be focusing more on providing students with information related to the available upper-secondary courses that are suitable to each student's ability credentials and future educational and occupational aspirations.

In the future I plan to expand this analysis by examining whether increased provision of information, advice and guidance in schools about available post-compulsory education routes is efficient in decreasing academic mismatch in upper-secondary education. Further, the role of educational and occupational aspirations in influencing academic match would be an interesting area to investigate. Unfortunately, the administrative data used in this study do not provide such information. For future research rich individual level survey data will be used to expand this investigation and study whether the lack of educational advice or the heterogeneous educational and professional aspirations among students are driving some of the socio-economic effect that has been identified in this analysis. 
Table 3: Socio-economic effect in academic match

\begin{tabular}{|c|c|c|c|c|}
\hline & $\begin{array}{c}\text { Specification } \\
(1) \\
\end{array}$ & $\begin{array}{c}\text { Specification } \\
(2) \\
\end{array}$ & $\begin{array}{c}\text { Specification } \\
(3) \\
\end{array}$ & $\begin{array}{c}\text { Specification } \\
(4) \\
\end{array}$ \\
\hline \multicolumn{5}{|l|}{ Socio-economic background } \\
\hline Middle-High SES & $\begin{array}{l}-0.015^{* * *} \\
(0.006)\end{array}$ & $\begin{array}{l}-0.052^{* * *} \\
(0.003)\end{array}$ & $\begin{array}{l}-0.049^{* * *} \\
(0.002)\end{array}$ & $\begin{array}{l}-0.026^{* * *} \\
(0.002)\end{array}$ \\
\hline \multirow[t]{2}{*}{ Middle SES } & 0.000 & $-0.086^{* * *}$ & $-0.082^{* * *}$ & $-0.048^{* * *}$ \\
\hline & $(0.007)$ & $(0.003)$ & $(0.003)$ & $(0.002)$ \\
\hline \multirow[t]{2}{*}{ Middle-Low SES } & $0.030^{* * *}$ & $-0.123^{* * *}$ & $-0.119^{* * *}$ & $-0.071^{* * *}$ \\
\hline & $(0.008)$ & $(0.004)$ & $(0.003)$ & $(0.002)$ \\
\hline \multirow[t]{2}{*}{ Lowest SES } & $0.083^{* * *}$ & $-0.159^{* * *}$ & $-0.161^{* * *}$ & $-0.087^{* * *}$ \\
\hline & $(0.010)$ & $(0.005)$ & $(0.004)$ & $(0.003)$ \\
\hline \multicolumn{5}{|l|}{ Control Variables } \\
\hline \multirow[t]{2}{*}{ KS2 test scores } & & $-0.030 * * *$ & $-0.033^{* * *}$ & $-0.036^{* * *}$ \\
\hline & & $(0.002)$ & $(0.002)$ & $(0.001)$ \\
\hline \multirow[t]{2}{*}{ KS3 level scores } & & $0.295^{* * *}$ & $0.232^{* * *}$ & $0.193^{* * *}$ \\
\hline & & $(0.003)$ & $(0.003)$ & $(0.002)$ \\
\hline \multirow[t]{2}{*}{ GCSE point score } & & $-0.717^{* * *}$ & $-0.775^{* * *}$ & $-0.718^{* * *}$ \\
\hline & & $(0.004)$ & $(0.003)$ & $(0.003)$ \\
\hline \multirow{2}{*}{$5 \geq A^{*}-\mathrm{C}$ GCSEs including Maths \& English } & & & $0.287^{* * *}$ & $0.258^{* * *}$ \\
\hline & & & $(0.003)$ & $(0.003)$ \\
\hline \multirow[t]{2}{*}{ Girl } & & & $0.036^{* * *}$ & $0.027 * * *$ \\
\hline & & & $(0.002)$ & $(0.002)$ \\
\hline \multirow[t]{2}{*}{ Asian } & & & $0.228^{* * *}$ & $0.193^{* * *}$ \\
\hline & & & $(0.005)$ & $(0.004)$ \\
\hline \multirow[t]{2}{*}{ Black } & & & $0.164^{* * *}$ & $0.117^{* * *}$ \\
\hline & & & $(0.006)$ & $(0.005)$ \\
\hline \multirow[t]{2}{*}{ Other } & & & $0.194^{* * *}$ & $0.144^{* * *}$ \\
\hline & & & $(0.010)$ & $(0.008)$ \\
\hline \multirow[t]{2}{*}{ Mixed } & & & $0.060^{* * *}$ & $0.039^{* * *}$ \\
\hline & & & $(0.005)$ & $(0.004)$ \\
\hline Observations & 391,651 & 391,651 & 391,651 & 391,651 \\
\hline Number of clusters & 3,076 & 3,076 & 3,076 & 3,076 \\
\hline R-squared & 0.00 & 0.58 & 0.61 & 0.64 \\
\hline School FEs & & & & $\checkmark$ \\
\hline
\end{tabular}

Notes: Post-compulsory education participants only. Omitted groups: Highest SES, Boy, White.

Standard errors clustered at secondary school level and reported in parentheses.

Significance levels: ${ }^{*} p<0.10,{ }^{* *} p<0.05,{ }^{* * * *} p<0.01$. 
Table 4: Socio-economic effect in academic match across ability quintiles

\begin{tabular}{|c|c|c|c|c|}
\hline & $\begin{array}{l}\text { Specification } \\
\text { (1) }\end{array}$ & $\begin{array}{c}\text { Specification } \\
(2)\end{array}$ & $\begin{array}{c}\text { Specification } \\
(3)\end{array}$ & $\begin{array}{c}\text { Specification } \\
(4)\end{array}$ \\
\hline \multicolumn{5}{|c|}{ Bottom Quintile of GCSE scores } \\
\hline Middle-High SES & $\begin{array}{l}-0.032^{* * *} \\
(0.008)\end{array}$ & $\begin{array}{l}-0.038^{* * *} \\
(0.008)\end{array}$ & $\begin{array}{l}-0.036^{* * *} \\
(0.008)\end{array}$ & $\begin{array}{l}-0.025^{* * *} \\
(0.008)\end{array}$ \\
\hline Middle SES & $\begin{array}{l}-0.020^{* * *} \\
(0.007)\end{array}$ & $\begin{array}{l}-0.032^{* * *} \\
(0.008)\end{array}$ & $\begin{array}{l}-0.030^{* * *} \\
(0.007)\end{array}$ & $\begin{array}{l}-0.019^{* *} \\
(0.008)\end{array}$ \\
\hline Middle-Low SES & $\begin{array}{l}0.000 \\
(0.008)\end{array}$ & $\begin{array}{l}-0.023^{* * *} \\
(0.008)\end{array}$ & $\begin{array}{l}-0.022^{* * *} \\
(0.008)\end{array}$ & $\begin{array}{l}-0.014^{*} \\
(0.008)\end{array}$ \\
\hline Lowest SES & $\begin{array}{l}0.055^{* * *} \\
(0.008)\end{array}$ & $\begin{array}{l}0.014^{*} \\
(0.008)\end{array}$ & $\begin{array}{l}0.015^{*} \\
(0.008)\end{array}$ & $\begin{array}{l}0.023^{* * *} \\
(0.008)\end{array}$ \\
\hline Observations & 97,909 & 97,909 & 97,909 & 97,909 \\
\hline Number of clusters & 2,989 & 2,989 & 2,989 & 2,989 \\
\hline R-squared & 0.00 & 0.03 & 0.03 & 0.11 \\
\hline \multicolumn{5}{|c|}{ Middle-Low Quintile of GCSE scores } \\
\hline Middle-High SES & $\begin{array}{l}-0.059^{* * *} \\
(0.006)\end{array}$ & $\begin{array}{l}-0.050^{* * *} \\
(0.005)\end{array}$ & $\begin{array}{l}-0.049^{* * *} \\
(0.005)\end{array}$ & $\begin{array}{l}-0.024^{* * *} \\
(0.004)\end{array}$ \\
\hline Middle SES & $\begin{array}{l}-0.091^{* * *} \\
(0.006)\end{array}$ & $\begin{array}{l}-0.075^{* * *} \\
(0.006)\end{array}$ & $\begin{array}{l}-0.077^{* * *} \\
(0.005)\end{array}$ & $\begin{array}{l}-0.041^{* * *} \\
(0.005)\end{array}$ \\
\hline Middle-Low SES & $\begin{array}{l}-0.126^{* * *} \\
(0.007)\end{array}$ & $\begin{array}{l}-0.098^{* * *} \\
(0.006)\end{array}$ & $\begin{array}{l}-0.106^{* * *} \\
(0.006)\end{array}$ & $\begin{array}{l}-0.057^{* * *} \\
(0.005)\end{array}$ \\
\hline Lowest SES & $\begin{array}{l}-0.200^{* * *} \\
(0.009)\end{array}$ & $\begin{array}{l}-0.146^{* * *} \\
(0.008)\end{array}$ & $\begin{array}{l}-0.168^{* * *} \\
(0.007)\end{array}$ & $\begin{array}{l}-0.082^{* * *} \\
(0.006)\end{array}$ \\
\hline Observations & 99,120 & 99,120 & 99,120 & 99,120 \\
\hline Number of clusters & 3,047 & 3,047 & 3,047 & 3,047 \\
\hline R-squared & 0.02 & 0.07 & 0.12 & 0.23 \\
\hline \multicolumn{5}{|c|}{ Middle-High Quintile of GCSE scores } \\
\hline Middle-High SES & $\begin{array}{l}-0.064^{* * *} \\
(0.005)\end{array}$ & $\begin{array}{l}-0.042^{* * *} \\
(0.004)\end{array}$ & $\begin{array}{l}-0.040^{* * *} \\
(0.004)\end{array}$ & $\begin{array}{l}-0.014^{* * *} \\
(0.003)\end{array}$ \\
\hline Middle SES & $\begin{array}{l}-0.117^{* * *} \\
(0.006)\end{array}$ & $\begin{array}{l}-0.078^{* * *} \\
(0.005)\end{array}$ & $\begin{array}{l}-0.074^{* * *} \\
(0.004)\end{array}$ & $\begin{array}{l}-0.033^{* * *} \\
(0.004)\end{array}$ \\
\hline Middle-Low SES & $\begin{array}{l}-0.187^{* * *} \\
(0.007)\end{array}$ & $\begin{array}{l}-0.123^{* * *} \\
(0.006)\end{array}$ & $\begin{array}{l}-0.118^{* * *} \\
(0.005)\end{array}$ & $\begin{array}{l}-0.057^{* * *} \\
(0.004)\end{array}$ \\
\hline Lowest SES & $\begin{array}{l}-0.294^{* * *} \\
(0.010)\end{array}$ & $\begin{array}{l}-0.178^{* * *} \\
(0.008)\end{array}$ & $\begin{array}{l}-0.173^{* * *} \\
(0.006)\end{array}$ & $\begin{array}{l}-0.076^{* * *} \\
(0.006)\end{array}$ \\
\hline Observations & 96,398 & 96,398 & 96,398 & 96,398 \\
\hline Number of clusters & 3,051 & 3,051 & 3,051 & 3,051 \\
\hline R-squared & 0.04 & 0.18 & 0.24 & 0.35 \\
\hline \multicolumn{5}{|c|}{ Highest Quintile of GCSE scores } \\
\hline Middle-High SES & $\begin{array}{l}-0.078^{* * *} \\
(0.008)\end{array}$ & $\begin{array}{l}-0.053^{* * *} \\
(0.007)\end{array}$ & $\begin{array}{l}-0.056^{* * *} \\
(0.007)\end{array}$ & $\begin{array}{l}-0.005 \\
(0.004)\end{array}$ \\
\hline Middle SES & $\begin{array}{l}-0.142^{* * *} \\
(0.011)\end{array}$ & $\begin{array}{l}-0.096^{* * *} \\
(0.010)\end{array}$ & $\begin{array}{l}-0.099^{* * *} \\
(0.010)\end{array}$ & $\begin{array}{l}-0.018^{* * *} \\
(0.005)\end{array}$ \\
\hline Middle-Low SES & $\begin{array}{l}-0.227^{* * *} \\
(0.013)\end{array}$ & $\begin{array}{l}-0.151^{* * *} \\
(0.011)\end{array}$ & $\begin{array}{l}-0.155^{* * *} \\
(0.011)\end{array}$ & $\begin{array}{l}-0.020^{* * *} \\
(0.005)\end{array}$ \\
\hline Lowest SES & $\begin{array}{l}-0.398^{* * *} \\
(0.019)\end{array}$ & $\begin{array}{l}-0.266^{* * *} \\
(0.015)\end{array}$ & $\begin{array}{l}-0.266^{* * *} \\
(0.014)\end{array}$ & $\begin{array}{l}-0.040^{* * *} \\
(0.007)\end{array}$ \\
\hline Observations & 98,224 & 98,224 & 98,224 & 98,224 \\
\hline Number of clusters & 3,010 & 3,010 & 3,010 & 3,010 \\
\hline R-squared & 0.05 & 0.10 & 0.12 & 0.43 \\
\hline Prior attainment (KS2, KS3) & & $\checkmark$ & $\checkmark$ & $\checkmark$ \\
\hline Demographics & & & $\checkmark$ & $\checkmark$ \\
\hline School FEs & & & & $\checkmark$ \\
\hline
\end{tabular}

Notes: Post-compulsory education participants only.

Omitted group: Highest SES. Standard errors clustered at secondary school level and reported in parentheses. Significance levels: ${ }^{*} p<0.10,{ }^{* *} p<0.05,{ }^{* * *} p<0.01$. 
Table 5: School composition of the undermatched, matched and overmatched students by socio-economic group

\begin{tabular}{|c|c|c|c|}
\hline & Undermatched & Matched & Overmatched \\
\hline \multicolumn{4}{|l|}{ Highest SES } \\
\hline$\%$ with FSM eligibility & $\begin{array}{l}7.76 \\
(7.78)\end{array}$ & $\begin{array}{l}7.03 \\
(7.14)\end{array}$ & $\begin{array}{c}9.22 \\
(9.44)\end{array}$ \\
\hline$\%$ achieving $5 \geq \mathrm{A}^{*}$-C GCSEs including Maths \& English & $\begin{array}{c}58.13 \\
(18.79)\end{array}$ & $\begin{array}{c}58.59 \\
(17.73)\end{array}$ & $\begin{array}{c}52.81 \\
(16.59)\end{array}$ \\
\hline$\%$ of White British & $\begin{array}{c}83.41 \\
(18.49)\end{array}$ & $\begin{array}{c}83.33 \\
(17.99)\end{array}$ & $\begin{array}{c}79.73 \\
(22.00)\end{array}$ \\
\hline Observations & 15,974 & 60,669 & 9,855 \\
\hline \multicolumn{4}{|l|}{ Middle-High SES } \\
\hline$\%$ with FSM eligibility & $\begin{array}{c}9.40 \\
(8.11)\end{array}$ & $\begin{array}{c}8.54 \\
(7.48)\end{array}$ & $\begin{array}{l}10.63 \\
(9.14)\end{array}$ \\
\hline$\%$ achieving $5 \geq \mathrm{A}^{*}$-C GCSEs including Maths \& English & $\begin{array}{c}52.26 \\
(19.16)\end{array}$ & $\begin{array}{c}53.19 \\
(18.38)\end{array}$ & $\begin{array}{c}47.08 \\
(16.26)\end{array}$ \\
\hline$\%$ of White British & $\begin{array}{c}85.30 \\
(18.66) \\
\end{array}$ & $\begin{array}{c}84.68 \\
(18.60) \\
\end{array}$ & $\begin{array}{c}81.75 \\
(21.73) \\
\end{array}$ \\
\hline Observations & 16,981 & 56,458 & 10,160 \\
\hline \multicolumn{4}{|l|}{ Middle SES } \\
\hline$\%$ with FSM eligibility & $\begin{array}{l}12.01 \\
(9.56)\end{array}$ & $\begin{array}{l}10.88 \\
(9.10)\end{array}$ & $\begin{array}{c}13.21 \\
(10.52)\end{array}$ \\
\hline$\%$ achieving $5 \geq \mathrm{A}^{*}$-C GCSEs including Maths \& English & $\begin{array}{c}46.62 \\
(18.66)\end{array}$ & $\begin{array}{c}48.04 \\
(18.53)\end{array}$ & $\begin{array}{c}42.08 \\
(15.85)\end{array}$ \\
\hline$\%$ of White British & $\begin{array}{r}85.09 \\
(19.63) \\
\end{array}$ & $\begin{array}{r}83.88 \\
(20.84) \\
\end{array}$ & $\begin{array}{c}80.63 \\
(24.01) \\
\end{array}$ \\
\hline Observations & 16,797 & 51,796 & 11,534 \\
\hline \multicolumn{4}{|l|}{ Middle-Low SES } \\
\hline$\%$ with FSM eligibility & $\begin{array}{c}16.06 \\
(11.50)\end{array}$ & $\begin{array}{c}14.38 \\
(11.19)\end{array}$ & $\begin{array}{c}17.14 \\
(12.09)\end{array}$ \\
\hline$\%$ achieving $5 \geq \mathrm{A}^{*}$-C GCSEs including Maths \& English & $\begin{array}{c}40.90 \\
(17.73)\end{array}$ & $\begin{array}{c}42.93 \\
(17.80)\end{array}$ & $\begin{array}{c}37.12 \\
(15.02)\end{array}$ \\
\hline$\%$ of White British & $\begin{array}{c}83.18 \\
(22.45)\end{array}$ & $\begin{array}{c}81.74 \\
(23.81)\end{array}$ & $\begin{array}{c}78.18 \\
(26.32)\end{array}$ \\
\hline Observations & 15,956 & 44,735 & 13,376 \\
\hline \multicolumn{4}{|l|}{ Lowest SES } \\
\hline$\%$ with FSM eligibility & $\begin{array}{c}24.78 \\
(14.49)\end{array}$ & $\begin{array}{c}22.23 \\
(14.07)\end{array}$ & $\begin{array}{c}23.86 \\
(13.69)\end{array}$ \\
\hline$\%$ achieving $5 \geq \mathrm{A}^{*}$-C GCSEs including Maths \& English & $\begin{array}{c}33.05 \\
(15.79)\end{array}$ & $\begin{array}{c}35.23 \\
(15.96)\end{array}$ & $\begin{array}{c}30.95 \\
(13.51)\end{array}$ \\
\hline$\%$ of White British & $\begin{array}{c}80.13 \\
(25.68)\end{array}$ & $\begin{array}{c}77.19 \\
(28.08)\end{array}$ & $\begin{array}{c}77.32 \\
(27.25)\end{array}$ \\
\hline Observations & 15,118 & 35,906 & 16,336 \\
\hline
\end{tabular}

Note: The numbers presented in each column are the mean values of each school characteristic for post-compulsory education participants in the analytical sample. The numbers in parentheses are the standard deviations. 
Table 6: School composition and academic match

\begin{tabular}{|c|c|c|c|}
\hline & $(1)$ & $(2)$ & $(3)$ \\
\hline$\%$ with FSM eligibility & $\begin{array}{l}-0.002^{* * *} \\
(0.000)\end{array}$ & & \\
\hline$\%$ achieving $5 \geq \mathrm{A}^{*}$-C GCSEs including Maths \& English & & $\begin{array}{l}0.002^{\text {*** }} \\
(0.000)\end{array}$ & \\
\hline$\%$ of White British & & & $\begin{array}{l}-0.001^{* * *} \\
(0.000)\end{array}$ \\
\hline Observations & 391,651 & 391,651 & 391,651 \\
\hline Number of clusters & 3,076 & 3,076 & 3,076 \\
\hline R-squared & 0.61 & 0.62 & 0.61 \\
\hline SES & $\checkmark$ & $\checkmark$ & $\checkmark$ \\
\hline Prior achievement (KS2, KS3, KS4) & $\checkmark$ & $\checkmark$ & $\checkmark$ \\
\hline Demographics & $\checkmark$ & $\checkmark$ & $\checkmark$ \\
\hline
\end{tabular}

Notes: Post-compulsory education participants only.

Standard errors clustered at secondary school level and reported in parentheses.

Significance levels: ${ }^{*} p<0.10,{ }^{* *} p<0.05,{ }^{* * *} p<0.01$.

Table 7: School composition and academic match across ability quintiles

\begin{tabular}{|c|c|c|c|c|}
\hline & $\begin{array}{l}\quad(1) \\
\text { Bottom } \\
\text { Quintile }\end{array}$ & $\begin{array}{l}\quad(2) \\
\text { Middle-Low } \\
\text { Quintile }\end{array}$ & $\begin{array}{l}\qquad(3) \\
\text { Middle-High } \\
\text { Quintile }\end{array}$ & $\begin{array}{l}\quad(4) \\
\text { Highest } \\
\text { Quintile }\end{array}$ \\
\hline$\%$ with FSM eligibility & $\begin{array}{l}0.001^{* * *} \\
(0.000)\end{array}$ & $\begin{array}{l}0.002^{* * *} \\
(0.000)\end{array}$ & $\begin{array}{l}-0.002^{* * *} \\
(0.000)\end{array}$ & $\begin{array}{l}-0.007^{* * *} \\
(0.001)\end{array}$ \\
\hline Observations & 97,909 & 99,120 & 96,398 & 98,224 \\
\hline Number of clusters & 2,989 & 3,047 & 3,051 & 3,010 \\
\hline R-squared & 0.03 & 0.07 & 0.25 & 0.13 \\
\hline $\begin{array}{l}\% \text { achieving } 5 \geq A^{*} \text {-C GCSEs } \\
\text { including Maths \& English }\end{array}$ & $\begin{array}{l}-0.001^{* * *} \\
(0.000)\end{array}$ & $\begin{array}{l}0.001^{* * *} \\
(0.000)\end{array}$ & $\begin{array}{l}0.002^{* * *} \\
(0.000)\end{array}$ & $\begin{array}{l}0.003^{* * *} \\
(0.000)\end{array}$ \\
\hline Observations & 97,909 & 99,120 & 96,398 & 98,224 \\
\hline Number of clusters & 2,989 & 3,047 & 3,051 & 3,010 \\
\hline R-squared & 0.03 & 0.07 & 0.25 & 0.13 \\
\hline$\%$ of White British & $\begin{array}{l}-0.001^{* * *} \\
(0.000)\end{array}$ & $\begin{array}{l}-0.003^{* * *} \\
(0.000)\end{array}$ & $\begin{array}{l}-0.001^{* * *} \\
(0.000)\end{array}$ & $\begin{array}{l}-0.000 \\
(0.000)\end{array}$ \\
\hline Observations & 97,909 & 99,120 & 96,398 & 98,224 \\
\hline Number of clusters & 2,989 & 3,047 & 3,051 & 3,010 \\
\hline R-squared & 0.03 & 0.09 & 0.25 & 0.12 \\
\hline SES & $\checkmark$ & $\checkmark$ & $\checkmark$ & $\checkmark$ \\
\hline Prior achievement (KS2, KS3) & $\checkmark$ & $\checkmark$ & $\checkmark$ & $\checkmark$ \\
\hline Demographics & $\checkmark$ & $\checkmark$ & $\checkmark$ & $\checkmark$ \\
\hline
\end{tabular}

Notes: Post-compulsory education participants only. Ability quintiles have been calculated based on individual GCSE point scores. Standard errors clustered at secondary school level and reported in parentheses. Significance levels: $* p<0.10,{ }^{* *} p<0.05,{ }^{* * *} p<0.01$. 
Table 8: Local Authority District (LAD) characteristics and academic match

\begin{tabular}{llll}
\hline & $(1)$ & $(2)$ & $(3)$ \\
\hline Urban LAD & 0.001 & & \\
\% with L4 Qualifications or above & $(0.004)$ & & \\
& & $0.003^{* * *}$ & \\
& & $(0.000)$ & \\
\% of 16-24 claimants & & $-0.006^{* * *}$ \\
& & & $(0.001)$ \\
\hline Observations & & & 391,651 \\
Number of clusters & 391,651 & 391,651 & 3,076 \\
R-squared & 3,076 & 3,076 & 0.62 \\
\hline SES & 0.62 & 0.62 & $\checkmark$ \\
Prior achievement (KS2, KS3, KS4) & $\checkmark$ & $\checkmark$ & $\checkmark$ \\
Demographics & $\checkmark$ & $\checkmark$ & $\checkmark$ \\
\hline
\end{tabular}

Notes: Post-compulsory education participants only.

Standard errors clustered at secondary school level and reported in parentheses.

Significance levels: ${ }^{*} p<0.10,{ }^{* *} p<0.05,{ }^{* * *} p<0.01$.

Table 9: Log income returns to academic assortative matching

\begin{tabular}{|c|c|c|c|c|c|c|}
\hline & \multicolumn{2}{|c|}{ Full sample } & \multicolumn{2}{|c|}{ Girls } & \multicolumn{2}{|c|}{ Boys } \\
\hline & $\begin{array}{l}\text { University } \\
\text { (1) }\end{array}$ & $\begin{array}{c}\text { No University } \\
(2)\end{array}$ & $\begin{array}{c}\text { University } \\
(3)\end{array}$ & $\begin{array}{c}\text { No University } \\
(4)\end{array}$ & $\begin{array}{c}\text { University } \\
(5)\end{array}$ & $\begin{array}{c}\text { No University } \\
(6)\end{array}$ \\
\hline Academic match & $\begin{array}{l}0.035^{* * *} \\
(0.007)\end{array}$ & $\begin{array}{l}0.088^{* * *} \\
(0.005)\end{array}$ & $\begin{array}{l}0.088^{* * *} \\
(0.010)\end{array}$ & $\begin{array}{l}0.182^{* * *} \\
(0.008)\end{array}$ & $\begin{array}{l}-0.022^{* *} \\
(0.011)\end{array}$ & $\begin{array}{l}0.019^{* * *} \\
(0.007)\end{array}$ \\
\hline Observations & 164,259 & 143,901 & 90,951 & 65,626 & 73,308 & 78,275 \\
\hline $\begin{array}{l}\text { Number of clusters } \\
\text { R-squared }\end{array}$ & $\begin{array}{l}3,061 \\
0.02\end{array}$ & $\begin{array}{l}3,052 \\
0.09\end{array}$ & $\begin{array}{l}2,879 \\
0.02\end{array}$ & $\begin{array}{l}2,874 \\
0.07\end{array}$ & $\begin{array}{l}2,822 \\
0.02\end{array}$ & $\begin{array}{l}2,831 \\
0.05\end{array}$ \\
\hline
\end{tabular}

Notes: Post-compulsory education participants matched to HMRC tax records only.

Standard errors clustered at secondary school level and reported in parentheses.

Significance levels: ${ }^{*} p<0.10,{ }^{* *} p<0.05, * * * p<0.01$.

Table 10: Log income returns to being less undermatched and more overmatched

\begin{tabular}{|c|c|c|c|c|c|c|}
\hline & \multicolumn{2}{|c|}{ Full sample } & \multicolumn{2}{|c|}{ Girls } & \multicolumn{2}{|c|}{ Boys } \\
\hline & $\begin{array}{c}\text { University } \\
(1)\end{array}$ & $\begin{array}{c}\text { No University } \\
(2)\end{array}$ & $\begin{array}{c}\text { University } \\
(3)\end{array}$ & $\begin{array}{c}\text { No University } \\
(4)\end{array}$ & $\begin{array}{c}\text { University } \\
(5)\end{array}$ & $\begin{array}{c}\text { No University } \\
(6)\end{array}$ \\
\hline Less undermatched & $\begin{array}{l}0.064^{* * *} \\
(0.008)\end{array}$ & $\begin{array}{l}0.101^{* * *} \\
(0.006)\end{array}$ & $\begin{array}{l}0.095^{* * *} \\
(0.010)\end{array}$ & $\begin{array}{l}0.170^{* * *} \\
(0.009)\end{array}$ & $\begin{array}{l}0.026^{* *} \\
(0.013)\end{array}$ & $\begin{array}{l}0.048^{* * *} * \\
(0.008)\end{array}$ \\
\hline More overmatched & $\begin{array}{l}-0.052^{* * *} \\
(0.010)\end{array}$ & $\begin{array}{l}0.040^{* * *} \\
(0.008)\end{array}$ & $\begin{array}{l}-0.014 \\
(0.014)\end{array}$ & $\begin{array}{l}0.112^{* * *} \\
(0.012)\end{array}$ & $\begin{array}{l}-0.086^{* * *} \\
(0.015)\end{array}$ & $\begin{array}{c}-0.008 \\
(0.010)\end{array}$ \\
\hline R-squared & 0.02 & 0.09 & 0.02 & 0.07 & 0.02 & 0.05 \\
\hline SES & $\checkmark$ & $\checkmark$ & $\checkmark$ & $\checkmark$ & $\checkmark$ & $\checkmark$ \\
\hline Prior achievement (KS2, KS3, KS4) & $\checkmark$ & $\checkmark$ & $\checkmark$ & $\checkmark$ & $\checkmark$ & $\checkmark$ \\
\hline Demographics & $\checkmark$ & $\checkmark$ & $\checkmark$ & $\checkmark$ & $\checkmark$ & $\checkmark$ \\
\hline
\end{tabular}




\section{References}

Belasco, A. S. and M. J. Trivette (2015). Aiming low: Estimating the scope and predictors of postsecondary undermatch. The Journal of Higher Education 86(2), 233-263.

Black, S. E., K. E. Cortes, and J. A. Lincove (2015). Academic undermatching of highachieving minority students: Evidence from race-neutral and holistic admissions policies. American Economic Review 105(5), 604-10.

Campbell, S., L. Macmillan, R. Murphy, G. Wyness, et al. (2019). Inequalities in student to course match: Evidence from linked administrative data. Technical report, Centre for Economic Performance, LSE.

Chowdry, H., C. Crawford, L. Dearden, A. Goodman, and A. Vignoles (2013). Widening participation in higher education: analysis using linked administrative data. Journal of the Royal Statistical Society: Series A (Statistics in Society) 176(2), 431-457.

Crawford, C. (2014). Socio-economic differences in university outcomes in the UK: dropout, degree completion and degree class. IFS Working Paper W14/31.

Crawford, C., P. Gregg, L. Macmillan, A. Vignoles, and G. Wyness (2016). Higher education, career opportunities and intergenerational inequality. Oxford Review of Economic Policy 32(4), 553-575.

Dillon, E. W. and J. A. Smith (2017). Determinants of the match between student ability and college quality. Journal of Labor Economics 35(1), 45-66.

Dilnot, C. (2016). How does the choice of A-level subjects vary with students' socioeconomic status in english state schools? British Educational Research Journal 42(6), $1081-1106$.

Dilnot, C. (2018). The relationship between A-level subject choice and league table score of university attended: the âfacilitatingâ, the âless suitableâ, and the counter-intuitive. Oxford Review of Education 44(1), 118-137.

Gibbons, S. and S. Machin (2003). Valuing English primary schools. Journal of Urban Economics 53(2), 197-219.

Hearn, J. C. (1991). Academic and nonacademic influences on the college destinations of 1980 high school graduates. Sociology of Education 64(3), 158-71.

Hoxby, C. M. and C. Avery (2012). The missing "one-offs": The hidden supply of highachieving, low income students. Technical report, National Bureau of Economic Research.

Hupkau, C., S. McNally, J. Ruiz-Valenzuela, and G. Ventura (2017). Post-compulsory education in England: choices and implications. National Institute Economic Review $240(1)$, R42-R57.

Jenkins, A., A. Vignoles, A. Wolf, and F. Galindo-Rueda (2003). The determinants and labour market effects of lifelong learning. Applied economics 35(16), 1711-1721.

Marsh, H. W. and K.-T. Hau (2003). Big-fish-little-pond effect on academic self-concept: A cross-cultural (26-country) test of the negative effects of academically selective schools. American psychologist 58(5), 364 .

McIntosh, S. and D. Morris (2018). Labour market outcomes of older versus younger apprentices: A comparison of earnings differentials. CVER Discussion Paper series DP016.

Roderick, M., V. Coca, and J. Nagaoka (2011). Potholes on the road to college: High school effects in shaping urban studentsâ participation in college application, four-year college enrollment, and college match. Sociology of Education 84(3), 178-211.

Sallee, J. M., A. M. Resch, and P. N. Courant (2008). On the optimal allocation of students and resources in a system of higher education. The BE Journal of Economic Analysis Es Policy 8(1).

Smith, J., M. Pender, and J. Howell (2013). The full extent of student-college academic undermatch. Economics of Education Review 32, 247-261.

Wolf, A. (2011). Review of vocational education: The Wolf report. 


\section{A Descriptive statistics}

\begin{tabular}{|c|c|c|c|c|c|c|}
\hline SES Quintile & $\begin{array}{c}(1) \\
\text { Highest } \\
\text { SES }\end{array}$ & $\begin{array}{c}(2) \\
\text { Middle-High } \\
\text { SES }\end{array}$ & $\begin{array}{c}(3) \\
\text { Middle } \\
\text { SES }\end{array}$ & $\begin{array}{c}(4) \\
\text { Middle-Low } \\
\text { SES }\end{array}$ & $\begin{array}{c}(5) \\
\text { Lowest } \\
\text { SES }\end{array}$ & Total \\
\hline \multicolumn{7}{|l|}{ Prior achievement (standardised) } \\
\hline KS2 scores & $\begin{array}{c}0.44 \\
(0.87)\end{array}$ & $\begin{array}{l}0.28 \\
(0.91)\end{array}$ & $\begin{array}{l}0.15 \\
(0.94)\end{array}$ & $\begin{array}{l}-0.05 \\
(0.99)\end{array}$ & $\begin{array}{l}-0.29 \\
(1.02)\end{array}$ & $\begin{array}{c}0.13 \\
(0.97)\end{array}$ \\
\hline KS3 level scores & $\begin{array}{l}0.54 \\
(0.85)\end{array}$ & $\begin{array}{l}0.37 \\
(0.88)\end{array}$ & $\begin{array}{c}0.20 \\
(0.90)\end{array}$ & $\begin{array}{l}-0.02 \\
(0.93)\end{array}$ & $\begin{array}{l}-0.35 \\
(0.95)\end{array}$ & $\begin{array}{c}0.18 \\
(0.95)\end{array}$ \\
\hline GCSE point score & $\begin{array}{l}0.50 \\
(0.78)\end{array}$ & $\begin{array}{l}0.38 \\
(0.82)\end{array}$ & $\begin{array}{c}0.25 \\
(0.85)\end{array}$ & $\begin{array}{l}0.07 \\
(0.91)\end{array}$ & $\begin{array}{l}-0.18 \\
(1.00)\end{array}$ & $\begin{array}{c}0.22 \\
(0.90)\end{array}$ \\
\hline \multicolumn{7}{|l|}{ Demographics } \\
\hline $5 \geq \mathrm{A}^{*}$-C GCSEs including Maths \& English & $\begin{array}{l}0.71 \\
(0.45)\end{array}$ & $\begin{array}{c}0.63 \\
(0.48)\end{array}$ & $\begin{array}{l}0.55 \\
(0.50)\end{array}$ & $\begin{array}{c}0.44 \\
(0.50)\end{array}$ & $\begin{array}{c}0.31 \\
(0.46)\end{array}$ & $\begin{array}{c}0.54 \\
(0.50)\end{array}$ \\
\hline Girl & $\begin{array}{c}0.50 \\
(0.50)\end{array}$ & $\begin{array}{c}0.51 \\
(0.50)\end{array}$ & $\begin{array}{c}0.51 \\
(0.50)\end{array}$ & $\begin{array}{l}0.51 \\
(0.50)\end{array}$ & $\begin{array}{c}0.51 \\
(0.50)\end{array}$ & $\begin{array}{c}0.51 \\
(0.50)\end{array}$ \\
\hline White & $\begin{array}{c}0.91 \\
(0.28)\end{array}$ & $\begin{array}{c}0.91 \\
(0.29)\end{array}$ & $\begin{array}{c}0.89 \\
(0.31)\end{array}$ & $\begin{array}{c}0.86 \\
(0.35)\end{array}$ & $\begin{array}{c}0.81 \\
(0.40)\end{array}$ & $\begin{array}{c}0.88 \\
(0.33)\end{array}$ \\
\hline Asian & $\begin{array}{c}0.04 \\
(0.20)\end{array}$ & $\begin{array}{c}0.05 \\
(0.21)\end{array}$ & $\begin{array}{c}0.06 \\
(0.23)\end{array}$ & $\begin{array}{c}0.07 \\
(0.26)\end{array}$ & $\begin{array}{c}0.11 \\
(0.32)\end{array}$ & $\begin{array}{c}0.06 \\
(0.25)\end{array}$ \\
\hline Black & $\begin{array}{c}0.02 \\
(0.13)\end{array}$ & $\begin{array}{c}0.02 \\
(0.14)\end{array}$ & $\begin{array}{c}0.03 \\
(0.16)\end{array}$ & $\begin{array}{c}0.04 \\
(0.20)\end{array}$ & $\begin{array}{c}0.04 \\
(0.21)\end{array}$ & $\begin{array}{c}0.03 \\
(0.17)\end{array}$ \\
\hline Other & $\begin{array}{c}0.01 \\
(0.08)\end{array}$ & $\begin{array}{c}0.01 \\
(0.07)\end{array}$ & $\begin{array}{c}0.01 \\
(0.07)\end{array}$ & $\begin{array}{c}0.01 \\
(0.09)\end{array}$ & $\begin{array}{c}0.01 \\
(0.08)\end{array}$ & $\begin{array}{c}0.01 \\
(0.08)\end{array}$ \\
\hline Mixed & $\begin{array}{c}0.02 \\
(0.15)\end{array}$ & $\begin{array}{c}0.02 \\
(0.14)\end{array}$ & $\begin{array}{c}0.02 \\
(0.14)\end{array}$ & $\begin{array}{c}0.02 \\
(0.15)\end{array}$ & $\begin{array}{c}0.03 \\
(0.16)\end{array}$ & $\begin{array}{c}0.02 \\
(0.15)\end{array}$ \\
\hline \multicolumn{7}{|l|}{ Upper-secondary qualification (ordered) } \\
\hline Q1: L1 Vocational & $\begin{array}{c}0.03 \\
(0.18)\end{array}$ & $\begin{array}{c}0.05 \\
(0.22)\end{array}$ & $\begin{array}{c}0.07 \\
(0.25)\end{array}$ & $\begin{array}{c}0.11 \\
(0.31)\end{array}$ & $\begin{array}{c}0.17 \\
(0.38)\end{array}$ & $\begin{array}{c}0.08 \\
(0.27)\end{array}$ \\
\hline Q2: L2 Vocational & $\begin{array}{c}0.11 \\
(0.32)\end{array}$ & $\begin{array}{c}0.16 \\
(0.37)\end{array}$ & $\begin{array}{c}0.20 \\
(0.40)\end{array}$ & $\begin{array}{c}0.25 \\
(0.44)\end{array}$ & $\begin{array}{c}0.32 \\
(0.47)\end{array}$ & $\begin{array}{c}0.20 \\
(0.40)\end{array}$ \\
\hline Q3: L3 Vocational & $\begin{array}{c}0.14 \\
(0.35)\end{array}$ & $\begin{array}{c}0.18 \\
(0.38)\end{array}$ & $\begin{array}{c}0.20 \\
(0.40)\end{array}$ & $\begin{array}{c}0.20 \\
(0.40)\end{array}$ & $\begin{array}{c}0.20 \\
(0.40)\end{array}$ & $\begin{array}{c}0.18 \\
(0.39)\end{array}$ \\
\hline Q4: AS levels & $\begin{array}{c}0.07 \\
(0.26)\end{array}$ & $\begin{array}{c}0.08 \\
(0.27)\end{array}$ & $\begin{array}{c}0.08 \\
(0.27)\end{array}$ & $\begin{array}{c}0.08 \\
(0.27)\end{array}$ & $\begin{array}{c}0.07 \\
(0.25)\end{array}$ & $\begin{array}{c}0.08 \\
(0.26)\end{array}$ \\
\hline Q5: A levels $<3 \mathrm{w} / \mathrm{o}$ facilitating subjects & $\begin{array}{c}0.09 \\
(0.29)\end{array}$ & $\begin{array}{c}0.09 \\
(0.29)\end{array}$ & $\begin{array}{c}0.09 \\
(0.29)\end{array}$ & $\begin{array}{c}0.09 \\
(0.28)\end{array}$ & $\begin{array}{c}0.07 \\
(0.26)\end{array}$ & $\begin{array}{c}0.09 \\
(0.28)\end{array}$ \\
\hline Q6: A levels $<3$ with 1 facilitating subject & $\begin{array}{c}0.04 \\
(0.20)\end{array}$ & $\begin{array}{c}0.04 \\
(0.20)\end{array}$ & $\begin{array}{c}0.04 \\
(0.20)\end{array}$ & $\begin{array}{c}0.04 \\
(0.19)\end{array}$ & $\begin{array}{c}0.03 \\
(0.16)\end{array}$ & $\begin{array}{c}0.04 \\
(0.19)\end{array}$ \\
\hline Q7: A levels $\geq 3 \mathrm{w} / \mathrm{o}$ facilitating subjects & $\begin{array}{c}0.10 \\
(0.30)\end{array}$ & $\begin{array}{c}0.09 \\
(0.28)\end{array}$ & $\begin{array}{c}0.07 \\
(0.26)\end{array}$ & $\begin{array}{c}0.06 \\
(0.24)\end{array}$ & $\begin{array}{c}0.04 \\
(0.20)\end{array}$ & $\begin{array}{c}0.07 \\
(0.26)\end{array}$ \\
\hline Q8: 2 A levels in 2 facilitating subjects & $\begin{array}{c}0.01 \\
(0.09)\end{array}$ & $\begin{array}{c}0.01 \\
(0.09)\end{array}$ & $\begin{array}{c}0.01 \\
(0.09)\end{array}$ & $\begin{array}{c}0.01 \\
(0.09)\end{array}$ & $\begin{array}{c}0.01 \\
(0.07)\end{array}$ & $\begin{array}{c}0.01 \\
(0.09)\end{array}$ \\
\hline Q9: A levels $\geq 3$ with 1 facilitating subject & $\begin{array}{c}0.15 \\
(0.36)\end{array}$ & $\begin{array}{c}0.12 \\
(0.33)\end{array}$ & $\begin{array}{c}0.10 \\
(0.30)\end{array}$ & $\begin{array}{c}0.07 \\
(0.26)\end{array}$ & $\begin{array}{c}0.05 \\
(0.21)\end{array}$ & $\begin{array}{c}0.10 \\
(0.30)\end{array}$ \\
\hline Q10: A levels $\geq 3$ with 2 facilitating subjects & $\begin{array}{c}0.13 \\
(0.34)\end{array}$ & $\begin{array}{c}0.10 \\
(0.30)\end{array}$ & $\begin{array}{c}0.08 \\
(0.27)\end{array}$ & $\begin{array}{c}0.06 \\
(0.23)\end{array}$ & $\begin{array}{c}0.03 \\
(0.17)\end{array}$ & $\begin{array}{c}0.08 \\
(0.28)\end{array}$ \\
\hline Q11 :A levels $\geq 3$ with $\geq 3$ facilitating subjects & $\begin{array}{c}0.11 \\
(0.31)\end{array}$ & $\begin{array}{c}0.08 \\
(0.26)\end{array}$ & $\begin{array}{c}0.06 \\
(0.23)\end{array}$ & $\begin{array}{c}0.04 \\
(0.19)\end{array}$ & $\begin{array}{c}0.02 \\
(0.14)\end{array}$ & $\begin{array}{c}0.06 \\
(0.24)\end{array}$ \\
\hline Observations & 86,498 & 83,599 & 80,127 & 74,067 & 67,360 & 391,651 \\
\hline
\end{tabular}

Note: The numbers presented in each column are the mean values of each characteristic for post-compulsory education participants in the analytical sample. The numbers in parentheses are the standard deviations. 


\section{B Income returns to academic assortative matching (complete results)}

All sample

Boys

\begin{tabular}{|c|c|c|c|c|c|c|}
\hline & $\begin{array}{l}\text { University } \\
(1)\end{array}$ & $\begin{array}{l}\text { No University } \\
(2)\end{array}$ & $\begin{array}{l}\text { University } \\
(3)\end{array}$ & $\begin{array}{l}\text { No University } \\
(4)\end{array}$ & $\begin{array}{l}\text { University } \\
(5)\end{array}$ & $\begin{array}{l}\text { No University } \\
(6)\end{array}$ \\
\hline Academic match & $\begin{array}{l}0.035^{* * *} \\
(0.007)\end{array}$ & $\begin{array}{l}0.088^{* * *} \\
(0.005)\end{array}$ & $\begin{array}{l}0.088^{* * *} \\
(0.010)\end{array}$ & $\begin{array}{l}0.182^{* * *} \\
(0.008)\end{array}$ & $\begin{array}{l}-0.022^{* *} \\
(0.011)\end{array}$ & $\begin{array}{l}0.019 * * * \\
(0.007)\end{array}$ \\
\hline Middle-High SES & $\begin{array}{l}-0.010 \\
(0.006)\end{array}$ & $\begin{array}{l}-0.006 \\
(0.007)\end{array}$ & $\begin{array}{l}-0.008 \\
(0.008)\end{array}$ & $\begin{array}{l}-0.012 \\
(0.010)\end{array}$ & $\begin{array}{l}-0.013 \\
(0.009)\end{array}$ & $\begin{array}{l}-0.001 \\
(0.009)\end{array}$ \\
\hline Middle SES & $\begin{array}{l}-0.037^{* * *} \\
(0.007)\end{array}$ & $\begin{array}{l}-0.018^{* *} \\
(0.007)\end{array}$ & $\begin{array}{l}-0.038^{* * *} \\
(0.009)\end{array}$ & $\begin{array}{l}-0.030^{* * *} \\
(0.010)\end{array}$ & $\begin{array}{l}-0.035^{* * *} \\
(0.010)\end{array}$ & $\begin{array}{l}-0.008 \\
(0.009)\end{array}$ \\
\hline Middle-Low SES & $\begin{array}{l}-0.053^{* * *} \\
(0.007)\end{array}$ & $\begin{array}{l}-0.061^{* * *} \\
(0.007)\end{array}$ & $\begin{array}{l}-0.055^{* * *} \\
(0.009)\end{array}$ & $\begin{array}{l}-0.093^{* * *} \\
(0.011)\end{array}$ & $\begin{array}{l}-0.050^{* * *} \\
(0.011)\end{array}$ & $\begin{array}{l}-0.034^{* * *} \\
(0.009)\end{array}$ \\
\hline Lowest SES & $\begin{array}{l}-0.113^{* * *} \\
(0.008)\end{array}$ & $\begin{array}{l}-0.133^{* * *} \\
(0.007)\end{array}$ & $\begin{array}{l}-0.110^{* * *} \\
(0.011)\end{array}$ & $\begin{array}{l}-0.160^{* * *} \\
(0.011)\end{array}$ & $\begin{array}{l}-0.117^{* * *} \\
(0.013)\end{array}$ & $\begin{array}{l}-0.109^{* * *} \\
(0.010)\end{array}$ \\
\hline KS2 scores & $\begin{array}{l}0.030^{* * *} \\
(0.005)\end{array}$ & $\begin{array}{l}0.031^{* * *} \\
(0.004)\end{array}$ & $\begin{array}{l}0.033^{* * *} \\
(0.007)\end{array}$ & $\begin{array}{l}0.021^{* * *} \\
(0.006)\end{array}$ & $\begin{array}{l}0.027^{* * *} \\
(0.008)\end{array}$ & $\begin{array}{l}0.039^{* * *} \\
(0.006)\end{array}$ \\
\hline KS3 Level scores & $\begin{array}{l}0.009 \\
(0.007)\end{array}$ & $\begin{array}{l}0.034^{* * *} \\
(0.005)\end{array}$ & $\begin{array}{l}-0.010 \\
(0.008)\end{array}$ & $\begin{array}{l}0.047^{* * *} \\
(0.008)\end{array}$ & $\begin{array}{l}0.031^{* * *} \\
(0.010)\end{array}$ & $\begin{array}{l}0.024^{* * *} \\
(0.007)\end{array}$ \\
\hline GCSE point score & $\begin{array}{l}0.089^{* * *} \\
(0.008)\end{array}$ & $\begin{array}{l}0.190^{* * *} \\
(0.006)\end{array}$ & $\begin{array}{l}0.132^{* * *} \\
(0.010)\end{array}$ & $\begin{array}{l}0.266^{* * *} \\
(0.009)\end{array}$ & $\begin{array}{l}0.045^{* * *} \\
(0.012)\end{array}$ & $\begin{array}{l}0.137^{* * *} \\
(0.007)\end{array}$ \\
\hline $5 \geq \mathrm{A}^{*}$-C GCSEs including Maths \& English & $\begin{array}{l}0.125^{* * *} \\
(0.007)\end{array}$ & $\begin{array}{l}0.040^{* * *} \\
(0.006)\end{array}$ & $\begin{array}{l}0.138^{* * *} \\
(0.009)\end{array}$ & $\begin{array}{l}0.048^{* * *} \\
(0.009)\end{array}$ & $\begin{array}{l}0.111^{* * *} \\
(0.010)\end{array}$ & $\begin{array}{l}0.026^{* * *} \\
(0.008)\end{array}$ \\
\hline Female & $\begin{array}{l}-0.048^{* * *} \\
(0.005)\end{array}$ & $\begin{array}{l}-0.355^{* * *} \\
(0.005)\end{array}$ & & & & \\
\hline Asian & $\begin{array}{l}0.056^{* * *} \\
(0.009)\end{array}$ & $\begin{array}{l}-0.116^{* * *} \\
(0.014)\end{array}$ & $\begin{array}{l}0.043^{* * *} \\
(0.011)\end{array}$ & $\begin{array}{l}0.039^{*} \\
(0.021)\end{array}$ & $\begin{array}{l}0.070^{* * *} \\
(0.012)\end{array}$ & $\begin{array}{l}-0.235^{* * *} \\
(0.019)\end{array}$ \\
\hline Black & $\begin{array}{l}-0.078^{* * *} \\
(0.013)\end{array}$ & $\begin{array}{l}-0.236^{* * *} \\
(0.019)\end{array}$ & $\begin{array}{l}-0.078^{* * *} \\
(0.016)\end{array}$ & $\begin{array}{l}-0.082^{* * *} \\
(0.026)\end{array}$ & $\begin{array}{l}-0.082^{* * *} \\
(0.021)\end{array}$ & $\begin{array}{l}-0.348^{* * *} \\
(0.025)\end{array}$ \\
\hline Other & $\begin{array}{l}-0.009 \\
(0.026)\end{array}$ & $\begin{array}{l}-0.142^{* * *} \\
(0.045)\end{array}$ & $\begin{array}{l}0.003 \\
(0.031)\end{array}$ & $\begin{array}{l}0.002 \\
(0.056)\end{array}$ & $\begin{array}{l}-0.023 \\
(0.040)\end{array}$ & $\begin{array}{l}-0.264^{* * *} \\
(0.064)\end{array}$ \\
\hline Mixed & $\begin{array}{l}-0.062^{* * *} \\
(0.015)\end{array}$ & $\begin{array}{l}-0.094^{* * *} \\
(0.017) \\
\end{array}$ & $\begin{array}{l}-0.062^{* * *} \\
(0.020)\end{array}$ & $\begin{array}{c}-0.042^{*} \\
(0.025) \\
\end{array}$ & $\begin{array}{l}-0.063^{* * *} \\
(0.023)\end{array}$ & $\begin{array}{l}-0.141^{* * *} \\
(0.024)\end{array}$ \\
\hline Observations & 164,259 & 143,901 & 90,951 & 65,626 & 73,308 & 78275 \\
\hline Number of clusters & 3,061 & 3,052 & 2,879 & 2,874 & 2,822 & 2,831 \\
\hline R-squared & 0.02 & 0.09 & 0.02 & 0.07 & 0.02 & 0.05 \\
\hline
\end{tabular}

Notes: Post-compulsory education participants matched to HMRC tax records only. Omitted groups: Highest SES, Boy, White.

Standard errors clustered at secondary school level and reported in parentheses. Significance levels: $* p<0.10,{ }^{* *} p<0.05, * * * p<0.01$. 
C Log income returns to academic assortative matching (categorical variable) controlling for both individual GCSE point score and upper-secondary qualification

\begin{tabular}{|c|c|c|c|c|c|c|}
\hline & \multicolumn{2}{|c|}{ All sample } & \multicolumn{2}{|c|}{ Girls } & \multicolumn{2}{|c|}{ Boys } \\
\hline & $\begin{array}{l}\text { University } \\
(1)\end{array}$ & $\begin{array}{l}\text { No University } \\
(2)\end{array}$ & $\begin{array}{l}\text { University } \\
(3)\end{array}$ & $\begin{array}{l}\text { No University } \\
(4)\end{array}$ & $\begin{array}{l}\text { University } \\
(5)\end{array}$ & $\begin{array}{l}\text { No University } \\
(6)\end{array}$ \\
\hline Undermatched & $\begin{array}{l}-0.013 \\
(0.009)\end{array}$ & $\begin{array}{l}-0.002 \\
(0.008)\end{array}$ & $\begin{array}{l}-0.017 \\
(0.011)\end{array}$ & $\begin{array}{l}0.007 \\
(0.012)\end{array}$ & $\begin{array}{l}-0.005 \\
(0.014)\end{array}$ & $\begin{array}{l}-0.009 \\
(0.011)\end{array}$ \\
\hline Overmatched & $\begin{array}{l}-0.067^{* * *} \\
(0.009)\end{array}$ & $\begin{array}{l}-0.041^{* * *} \\
(0.008)\end{array}$ & $\begin{array}{l}-0.056^{* * *} \\
(0.012) \\
\end{array}$ & $\begin{array}{l}-0.033^{* * *} \\
(0.012)\end{array}$ & $\begin{array}{l}-0.073^{* * *} \\
(0.013)\end{array}$ & $\begin{array}{l}-0.044^{* * *} \\
(0.011)\end{array}$ \\
\hline Observations & 164,259 & 143,901 & 90,951 & 65,626 & 73,308 & 78,275 \\
\hline Number of clusters & 3,061 & 3,052 & 2,879 & 2,874 & 2,822 & 2,831 \\
\hline R-squared & 0.02 & 0.10 & 0.02 & 0.07 & 0.02 & 0.06 \\
\hline SES & $\checkmark$ & $\checkmark$ & $\checkmark$ & $\checkmark$ & $\checkmark$ & $\checkmark$ \\
\hline Upper-secondary qualification & $\checkmark$ & $\checkmark$ & $\checkmark$ & $\checkmark$ & $\checkmark$ & $\checkmark$ \\
\hline Prior achievement (KS2, KS3, KS4) & $\checkmark$ & $\checkmark$ & $\checkmark$ & $\checkmark$ & $\checkmark$ & $\checkmark$ \\
\hline Demographics & $\checkmark$ & $\checkmark$ & $\checkmark$ & $\checkmark$ & $\checkmark$ & $\checkmark$ \\
\hline
\end{tabular}

Notes: Post-compulsory education participants matched to HMRC tax records only,

Standard errors clustered at secondary school level and reported in parentheses.

Significance levels: ${ }^{*} p<0.10,{ }^{* *} p<0.05,{ }^{* * *} p<0.01$. 